medRxiv preprint doi: https://doi.org/10.1101/2021.05.10.21256920; this version posted May 11, 2021. The copyright holder for this preprint

(which was not certified by peer review) is the author/funder, who has granted medRxiv a license to display the preprint in perpetuity.

It is made available under a CC-BY-NC 4.0 International license .

\title{
Comparison of Mental Health Symptoms prior to and during COVID-19: Evidence from a
}

\section{Living Systematic Review and Meta-analysis}

Ying Sun, $\mathrm{MPH}^{1}$; Yin Wu, $\mathrm{PhD}^{1,2}$; Olivia Bonardi ${ }^{1}$; Ankur Krishnan, $\mathrm{MSc}^{1}$; Chen He, MScPH ${ }^{1}$; Jill

T. Boruff, MLIS ${ }^{3}$; Danielle B. Rice, MSc ${ }^{1,4}$; Yutong Wang ${ }^{1}$; Xiaowen Jiang, BA ${ }^{1}$; Kexin Li, BSc ${ }^{1}$;

Sarah Markham, $\mathrm{PhD}^{5}$; Brooke Levis, $\mathrm{PhD}^{6}$; Marleine Azar, MSc ${ }^{1}$; lan Thombs-Vite ${ }^{1}$; Dipika

Neupane, MSc ${ }^{1}$; Tiffany Dal Santo ${ }^{1,4}$; Amina Tasleem ${ }^{1,4}$; Anneke Yao ${ }^{1,4}$; Branka Agic, MD ${ }^{7,8}$;

Christine Fahim, $\mathrm{PhD}^{9}$; Michael S. Martin, $\mathrm{PhD}^{10,11}$; Sanjeev Sockalingam, MD ${ }^{7,12}$; Gustavo

Turecki, MD ${ }^{2,13}$; Andrea Benedetti, $\mathrm{PhD}^{14-16}$; Brett D. Thombs, $\mathrm{PhD}^{1,2,4,14,15,17,18}$

${ }^{1}$ Lady Davis Institute for Medical Research, Jewish General Hospital, Montréal, Québec,

Canada; ${ }^{2}$ Department of Psychiatry, McGill University, Montréal, Québec, Canada; ${ }^{3}$ Schulich

Library of Physical Sciences, Life Sciences, and Engineering, McGill University, Montréal,

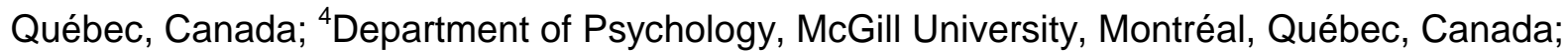

${ }^{5}$ Department of Biostatistics and Health Informatics, King's College London, London, UK;

${ }^{6}$ Centre for Prognosis Research, School of Medicine, Keele University, Staffordshire, UK;

${ }^{7}$ Centre for Addiction and Mental Health, Toronto, Ontario, Canada; ${ }^{8}$ Dalla Lana School of

Public Health, University of Toronto, Toronto, Ontario, Canada; ${ }^{9}$ Li Ka Shing Knowledge

Institute, Unity Health Toronto, Toronto, Ontario, Canada; ${ }^{10}$ School of Epidemiology and Public

Health, University of Ottawa; Ontario, Canada; ${ }^{11}$ Correctional Service of Canada, Ottawa,

Ontario, Canada; ${ }^{12}$ Department of Psychiatry, University of Toronto, Toronto, Ontario, Canada;

${ }^{13}$ McGill Group for Suicide Studies, Douglas Mental Health University Institute, McGill

University, Montreal, Quebec, Canada; ${ }^{14}$ Department of Epidemiology, Biostatistics and

Occupational Health, McGill University, Montréal, Québec, Canada; ${ }^{15}$ Department of Medicine,

McGill University, Montréal, Québec, Canada; ${ }^{16}$ Respiratory Epidemiology and Clinical

Research Unit, McGill University Health Centre, Montréal, Québec, Canada; ${ }^{17}$ Department of

NOTE: This preprint reports new research that has not been certified by peer review and should not be used to guide clinical practice. 1 
medRxiv preprint doi: https://doi.org/10.1101/2021.05.10.21256920; this version posted May 11, 2021. The copyright holder for this preprint (which was not certified by peer review) is the author/funder, who has granted medRxiv a license to display the preprint in perpetuity. It is made available under a CC-BY-NC 4.0 International license .

Educational and Counselling Psychology, McGill University, Montréal, Québec, Canada;

${ }^{18}$ Biomedical Ethics Unit, McGill University, Montréal, Québec, Canada.

\section{Corresponding author:}

Brett D. Thombs, PhD; Jewish General Hospital; 4333 Cote Ste Catherine Road; Montreal, Quebec, Canada, H3T 1E4; Tel (514) 340-8222 ext. 25112; E-mail: brett.thombs@mcgill.ca ORCID: 0000-0002-5644-8432

Word count: 4,934 
medRxiv preprint doi: https://doi.org/10.1101/2021.05.10.21256920; this version posted May 11, 2021. The copyright holder for this preprint (which was not certified by peer review) is the author/funder, who has granted medRxiv a license to display the preprint in perpetuity. It is made available under a CC-BY-NC 4.0 International license .

\section{ABSTRACT}

Objectives: The rapid pace, high volume, and limited quality of mental health evidence being generated during COVID-19 poses a barrier to effective decision-making. The objective of the present report is to compare mental health outcomes assessed during COVID-19 to outcomes prior to COVID-19 in the general population and other population groups.

Design: Living systematic review.

Data Sources: MEDLINE (Ovid), PsycINFO (Ovid), CINAHL (EBSCO), EMBASE (Ovid), Web of Science Core Collection: Citation Indexes, China National Knowledge Infrastructure, Wanfang, medRxiv (preprints), and Open Science Framework Preprints (preprint server aggregator). The initial search was conducted on April 13, 2020 with ongoing weekly updates. Eligibility criteria for selecting studies: For this report, we included studies that compared general mental health, anxiety symptoms, or depression symptoms, assessed January 1, 2020 or later, to the same outcomes collected between January 1, 2018 and December 31, 2019. We required $\geq 90 \%$ of participants pre-COVID-19 and during COVID-19 to be the same or the use of statistical methods to address missing data. For population groups with continuous outcomes for at least three studies in an outcome domain, we conducted restricted maximum-likelihood random-effects meta-analyses.

Results: As of March 22, 2021, we had identified 36 unique eligible studies with data from 33 cohorts. All reported COVID-19 outcomes between March and June 2020, and 3 studies also reported outcomes between September and November 2020. Estimates of changes in general mental health were close to zero in the general population (standardized mean difference [SMD] $=0.02,95 \% \mathrm{Cl}-0.11$ to $0.16, \mathrm{I}^{2}=94.6 \% ; 4$ studies, $\left.\mathrm{N}=19,707\right)$ and among older adults $(\mathrm{SMD}=$ $0.02,95 \% \mathrm{Cl}-0.11$ to $0.16, \mathrm{I}^{2}=90.4 \%$; 4 studies, $\left.\mathrm{N}=5,520\right)$ and university students (SMD = $0.01,95 \% \mathrm{Cl}-0.33$ to $0.30, \mathrm{I}^{2}=92.0 \%$; 3 studies, $\left.\mathrm{N}=3,372\right)$. Changes in anxiety symptoms were close to zero and not statistically significant in university students (SMD $=0.00,95 \% \mathrm{Cl}$ 0.35 to $0.36, \mathrm{I}^{2}=95.4 \%$; 5 studies, $\left.\mathrm{N}=1,537\right)$; women or females $(\mathrm{SMD}=0.02,95 \% \mathrm{Cl}-0.35$ to 
medRxiv preprint doi: https://doi.org/10.1101/2021.05.10.21256920; this version posted May 11, 2021. The copyright holder for this preprint (which was not certified by peer review) is the author/funder, who has granted medRxiv a license to display the preprint in perpetuity. It is made available under a CC-BY-NC 4.0 International license .

$0.39, \mathrm{I}^{2}=92.3 \% ; 3$ studies, $\left.\mathrm{N}=2,778\right)$; and men or males $\left(\mathrm{SMD}=0.07,95 \% \mathrm{Cl}-0.01\right.$ to $0.15 ; \mathrm{I}^{2}$ $=0.01 \%$; 3 studies, $N=1,250$ ); anxiety symptoms increased, however, among people with preexisting medical conditions $\left(\mathrm{SMD}=0.27,95 \% \mathrm{Cl} 0.01\right.$ to $0.54, \mathrm{I}^{2}=91.0 \% ; 3$ studies, $\mathrm{N}=2,053$ ). Changes in depression symptoms were close to zero or small and not statistically significant among university students $\left(\mathrm{SMD}=0.19,95 \% \mathrm{Cl}-0.08\right.$ to $0.45, \mathrm{I}^{2}=91.8 \% ; 5$ studies, $\left.\mathrm{N}=1,537\right)$; people with pre-existing medical conditions $\left(\mathrm{SMD}=0.01,95 \% \mathrm{Cl}-0.15\right.$ to $0.17, \mathrm{I}^{2}=14.9 \% ; 3$ studies, $\mathrm{N}=2,006)$; women or females $\left(\mathrm{SMD}=0.21,95 \% \mathrm{Cl}-0.14\right.$ to $0.55, \mathrm{I}^{2}=91.2 \% ; 3$ studies, $N=2,843)$; and men or males $\left(S M D=0.00,95 \% \mathrm{Cl}-0.21\right.$ to $0.22 ; I^{2}=92.3 \% ; 4$ studies, $N=3,661$ ). In 3 studies with data from both March to June 2020 and September to November 2020, symptoms were unchanged from pre-COVID-19 at both time points or there were increases at the first assessment that had largely dissipated by the second assessment. Conclusions: Evidence does not suggest a widespread negative effect on mental health symptoms in COVID-19, although it is possible that gaps in data have not allowed identification of changes in some vulnerable groups. Continued updating is needed as evidence accrues. Funding: Canadian Institutes of Health Research (CMS-171703; MS1-173070); McGill Interdisciplinary Initiative in Infection and Immunity Emergency COVID-19 Research Fund (R242).

Registration: PROSPERO (CRD42020179703); registered on April 17, 2020. 
medRxiv preprint doi: https://doi.org/10.1101/2021.05.10.21256920; this version posted May 11, 2021. The copyright holder for this preprint (which was not certified by peer review) is the author/funder, who has granted medRxiv a license to display the preprint in perpetuity. It is made available under a CC-BY-NC 4.0 International license .

The SARS-CoV-2 coronavirus disease (COVID-19) pandemic has led to over 3 million deaths worldwide. ${ }^{1}$ It has disrupted lives of people around the world due to its rapid spread, mortality, disruption of the social fabric, toll on health care systems, and devastating economic impact. $^{2,3}$ There is concern about effects on mental health, particularly among vulnerable populations.

The sheer volume and low quality of information on mental health in COVID-19 being generated and disseminated through academic channels and the media, however, poses a substantial barrier to effective synthesis and decision-making. ${ }^{4,5}$ Thousands of cross-sectional studies have published proportions of participants with scores above thresholds on easy-toadminister mental health measures and interpreted results as "prevalence" of mental health problems, attributable to COVID-19. ${ }^{4}$ These measures, however, are not intended for this purpose. Rather, thresholds on these measures are typically set to cast a wide net for screening, and proportions of people above thresholds dramatically overestimate prevalence compared to validated methods based on diagnostic interviews. ${ }^{6-10}$ In normal times, proportions of people above thresholds vary dramatically, even when the same measure and threshold are used. For example, the proportion of participants with scores of 10 or higher on the Patient Health Questionnaire-9 (PHQ-9), ${ }^{11}$ a commonly used depression symptom measure, in large, randomly selected, regional or national general population samples pre-COVID-19, has been reported as $4 \%$ in Hong Kong $(\mathrm{N}=6,028) ;{ }^{12} 6 \%$ in Germany $(\mathrm{N}=5,018) ;{ }^{13} 7 \%$ in Shanghai, China $(\mathrm{N}=$ $1,045) ;{ }^{14} 8 \%$ in the United States $(N=10,257) ;{ }^{15} 8 \%$ in Alberta, Canada $(N=3,304) ;{ }^{16} 11 \%$ in Sweden $(N=3,001),{ }^{17}$ and $22 \%$ in Jiangsu, China $(N=8,400) .{ }^{18}$ Making matters worse, hundreds of different measure and threshold combinations are being used to report "prevalence". Further compounding this problem, media stories have uncritically reported results from unvalidated survey tools or single items that inquire about mental health and well-being in COVID-19 and concluded that we are experiencing a "mental health pandemic" or "tsunami" of mental health consequences from COVID-19. ${ }^{19}$ 
medRxiv preprint doi: https://doi.org/10.1101/2021.05.10.21256920; this version posted May 11, 2021. The copyright holder for this preprint (which was not certified by peer review) is the author/funder, who has granted medRxiv a license to display the preprint in perpetuity. It is made available under a CC-BY-NC 4.0 International license .

Evidence from longitudinal cohorts that compare mental health symptoms from prior to COVID-19 to assessments done during the pandemic is critically needed to assess the degree of mental health changes, the nature of any changes, and who may be affected. Many systematic reviews have been published on mental health symptoms in COVID-19; however, all that we have identified have reported proportions of participants above questionnaire thresholds in cross-sectional studies.

We are conducting a series of living systematic reviews ${ }^{20}$ on mental health in COVID-19, including a review of longitudinal studies that compare mental health in COVID-19 to mental health prior to the pandemic or across points during the pandemic. ${ }^{4,21}$ Living systematic reviews ${ }^{20}$ are logistically challenging but highly valuable when (1) important decisions to be made merit the resources involved; (2) low-certainty in existing evidence poses a barrier to decision-making; and (3) emerging evidence may inform decisions, as is the case for mental health in COVID-19.

The objective of the present report is to evaluate changes in mental health symptoms in COVID-19 by comparing studies with outcomes assessed during COVID-19 to outcomes from the same cohort of participants prior to COVID-19 in the general population and other population groups.

\section{METHODS}

Our set of systematic reviews on mental health in COVID-19, which include longitudinal studies of symptoms and studies of interventions, were registered together in the PROSPERO prospective register of systematic reviews (CRD 42020179703). A protocol was uploaded to the Open Science Framework (https://osf.io/96csg/) prior to initiation. ${ }^{22}$ Results from studies included in our reviews are posted online (https://www.depressd.ca/covid-19-mental-health). ${ }^{4}$ The present report is a subset of the overall review of longitudinal studies and includes evidence from studies that assessed general mental health, anxiety symptoms, or depression symptoms 
medRxiv preprint doi: https://doi.org/10.1101/2021.05.10.21256920; this version posted May 11, 2021. The copyright holder for this preprint (which was not certified by peer review) is the author/funder, who has granted medRxiv a license to display the preprint in perpetuity. It is made available under a CC-BY-NC 4.0 International license .

during COVID-19 and prior to the pandemic. Results are reported in accordance with the PRISMA statement. ${ }^{23}$

\section{Eligible Studies}

Studies on any population were included in the present report if they compared eligible outcomes collected between January 1, 2018 and December 31, 2019, when China first reported COVID-19 to the World Health Organization, ${ }^{24}$ to the same outcomes collected January 1, 2020 or later. We required studies to report data from comparison samples with at least $90 \%$ of the same participants pre- and during COVID-19 or to use statistical methods to account for missing participant data. Studies with $<100$ participants were excluded due to their limited value for estimating changes.

Eligible outcomes in our main systematic review of longitudinal studies included (1) continuous scores on a validated mental health symptom questionnaire; (2) the proportion of participants above a threshold on a validated mental health symptom questionnaire; and (3) the proportion of participants meeting diagnostic criteria for a mental disorder using a validated diagnostic interview. In our main systematic review, mental health outcomes were defined broadly to include, for example, symptoms of anxiety, symptoms of depression, general mental health, stress, loneliness, anger, grief, burnout, other emotional disturbances, and emotional well-being. In the present report, we included only general mental health, anxiety symptoms, and depression symptoms because relatively few studies reported on other outcome domains. General mental health included measures of mental health quality of life, general symptoms or well-being, and combined symptom domains (e.g., symptoms of anxiety and depression). Results from other outcome domains are available online (https://www.depressd.ca/covid-19mental-health).

\section{Identification and Selection of Eligible Studies}

The same search strategies were used for all research questions in our systematic reviews. We searched MEDLINE (Ovid), PsycINFO (Ovid), CINAHL (EBSCO), EMBASE (Ovid), 
medRxiv preprint doi: https://doi.org/10.1101/2021.05.10.21256920; this version posted May 11, 2021. The copyright holder for this preprint (which was not certified by peer review) is the author/funder, who has granted medRxiv a license to display the preprint in perpetuity. It is made available under a CC-BY-NC 4.0 International license .

Web of Science Core Collection: Citation Indexes, China National Knowledge Infrastructure, Wanfang, medRxiv (preprints), and Open Science Framework Preprints (preprint server aggregator), using a search strategy designed and built by an experienced health sciences librarian. The China National Knowledge Infrastructure and Wanfang databases were searched using Chinese search terms chosen based on our English-language search strategy. The speed of the project launch did not allow for formal search strategy peer review; however, COVID-19 terms were developed in collaboration with other librarians working on the topic. See Supplementary Material 1 for all search strategies. Our initial search was conducted from December 31, 2019 to April 13, 2020, then automated searches were set for daily updates. On December 28, 2020, we converted to weekly updates to improve processing efficiency.

Search results were uploaded into the systematic review software DistillerSR (Evidence Partners, Ottawa, Canada), where duplicate references were identified and removed. Two independent reviewers evaluated titles and abstracts in random order. If either reviewer deemed a study potentially eligible, a full-text review was completed, also by two independent reviewers. Discrepancies at the full-text level were resolved through consensus, with a third investigator consulted as necessary. To ensure accurate identification of eligible studies, a coding guide with inclusion and exclusion criteria was developed and pre-tested, and all team members were trained over several sessions. See Supplementary Material 2.

\section{Data Extraction and Synthesis}

For each included study, one reviewer extracted data using a pre-specified standardized form, and a second reviewer validated the extracted data using the DistillerSR Quality Control function. Reviewers extracted (1) publication characteristics (e.g., first author, publication year, journal); (2) population characteristics and demographics, including study eligibility criteria, recruitment method, number of participants, timing of assessments, age, and population group (general population, older adults, young adults, children and adolescents, parents, university students, people with pre-existing medical conditions, medical staff, and groups defined by sex 
medRxiv preprint doi: https://doi.org/10.1101/2021.05.10.21256920; this version posted May 11, 2021. The copyright holder for this preprint (which was not certified by peer review) is the author/funder, who has granted medRxiv a license to display the preprint in perpetuity. It is made available under a CC-BY-NC 4.0 International license .

or gender with studies in present report); (3) mental health assessment measures and outcomes; and (4) adequacy of study methods and reporting. Adequacy of study methods and reporting was assessed using an adapted version of the Joanna Briggs Institute Checklist for Prevalence Studies, which included items that assessed the appropriateness of the sampling frame for the target population, appropriateness of recruiting methods, adequacy of sample size, description of setting and participants, participation or response rate, methods for outcome assessment, standardization of assessments across participants, appropriateness of statistical analyses, and follow-up rate. ${ }^{25}$ See Supplementary Material 3.

For each continuous outcome, we extracted a standardized mean difference (SMD) effect size with 95\% confidence intervals (Cls) for the change from pre-COVID-19 to during COVID-19. If not provided, we calculated it using Hedges' $g^{26}$ as $g=$ mean $_{\text {change }} /$ standard deviation $_{\text {within }} \mathrm{x}$ the Hedges' g adjustment factor, as described by Borenstein et al. ${ }^{27}$ In this report, we present SMDs as positive when mental health worsened from pre-COVID-19 to COVID-19 and negative when it improved. For proportions, if 95\% Cls were not reported, we generated them. For point estimates pre-COVID-19 and during COVID-19, we used Agresti and Coull's approximate method for binomial proportions. ${ }^{28}$ For changes in proportions, we used Newton's method for differences between binomial proportions based on paired data. ${ }^{29}$ We assumed that $50 \%$ of cases pre-COVID-19 continued to be cases during COVID-19 and confirmed that results did not differ substantively if we used values from $30 \%$ to $70 \%$.

We prioritized continuous data when both continuous and dichotomous results were reported due to pitfalls in interpreting proportions of participants crossing a dichotomous threshold. See Box 1 on interpreting outcomes from mental health symptom measures. For each population group with continuous outcomes for at least three studies in an outcome domain, SMDs were pooled across studies via restricted maximum-likelihood random-effects meta-analysis. Heterogeneity was assessed with the $\mathrm{I}^{2}$ statistic. For studies where more than one continuous outcome in a domain was assessed (e.g., two depression symptom measures), 
medRxiv preprint doi: https://doi.org/10.1101/2021.05.10.21256920; this version posted May 11, 2021. The copyright holder for this preprint (which was not certified by peer review) is the author/funder, who has granted medRxiv a license to display the preprint in perpetuity. It is made available under a CC-BY-NC 4.0 International license .

we pooled the relevant SMDs prior to fitting the meta-analysis, so that each study contributed only one observation. For one study ${ }^{30}$ that calculated change based on both a difference with the last pre-COVID-19 cohort assessment and via a fixed effects regression that included all pre-COVID-19 assessments, we included simple difference-based estimates in our metaanalyses. Meta-analysis was performed in $R$ ( $R$ version 3.6.3, RStudio Version 1.2.5042), using the rma.uni function in the metafor package.$^{31}$ Forest plots were generated using the forest.rma function in metafor.

\section{Patient and Public Involvement}

Dr. Sarah Markham, who is an experienced patient advisor and member of BMJ's International Patient Panel, was included as a member of the research team from the inception of the project. She provided input on the project design, underwent training on procedures used in the study, and was involved in selection of eligible studies. She reviewed and provided comments on the content of this article.

\section{Amendments to Protocol}

Our systematic review was quickly designed and initiated in April 2020, and several amendments or clarifications were made. First, we changed from daily to weekly search updates on December 28, 2020 for more efficient reference processing. Second, on January 27, 2021 we made a minor change to search strategies to incorporate a new physical distancing subject heading created for COVID-19. Third, we made several amendments to Chineselanguage search strategies to facilitate processing (see Supplementary Material 1). Fourth, we added a criterion to stipulate that eligible pre-COVID-19 assessments had to be completed between January 1, 2018 and December 31, 2019. We added this criterion because we had not anticipated comparisons of outcomes during COVID-19 to outcomes assessed many years prior, which in some cases occurred during a different developmental life stage.

\section{RESULTS}

\section{Search Results and Selection of Eligible Studies}


medRxiv preprint doi: https://doi.org/10.1101/2021.05.10.21256920; this version posted May 11, 2021. The copyright holder for this preprint (which was not certified by peer review) is the author/funder, who has granted medRxiv a license to display the preprint in perpetuity. It is made available under a CC-BY-NC 4.0 International license .

As of March 22, 2021, we had identified 45,777 unique titles and abstracts from our database search. Of these, we excluded 45,251 after title and abstract review and 394 after fulltext review, leaving 132 studies with longitudinal data collection. Of those, 85 studies only assessed outcomes longitudinally during the pandemic period and did not include pre-COVID19 data, 2 studies only assessed outcomes (e.g., loneliness) not included in the present report, 3 studies only collected pre-COVID-19 data prior to 2018, 1 study used the same outcome measure but for different time periods pre-COVID-19 (worst month in last year) and COVID-19 (last month), and 5 studies reported data that were from the same dataset as another study, leaving 36 unique studies that reported data from 33 cohorts for inclusion (Figure 1). ${ }^{30,32-66}$

\section{Characteristics of Included Studies}

Table 1 shows characteristics of included studies. All cohorts reported COVID-19 outcome data collected between March and June 2020. Two large national probability-based cohorts from the United Kingdom ${ }^{30,34}$ and the Netherlands ${ }^{36,37,41}$ and a cohort of people with a preexisting medical condition ${ }^{61}$ also included data collected between September and November 2020.

There were 7 studies $^{30,32-37}$ that reported on 5 different general population cohorts, including large national probability-based samples from the United Kingdom ( $N=10,918$ to $15,376)^{30,34}$ and the Netherlands $(\mathrm{N}=3,983 \text { to } 4,064)^{36,37}$ and 3 convenience samples with 102 to 218 participants per study from Germany, ${ }^{32}$ Italy ${ }^{33}$ and from multiple countries via an online crowdsourcing platform. ${ }^{35}$

There were 5 studies of older adults, including one $(N=1,679)^{41}$ that reported subgroup data from the large Dutch national probability sample. ${ }^{36,37}$ There were also large nationally sampled studies from the United Kingdom $(N=3,281),{ }^{38}$ Sweden $(N=1,071),{ }^{39}$ and China $(N=$ $6,467)^{42}$ plus a small study from Scotland $(\mathrm{N}=137) .{ }^{40}$ 
medRxiv preprint doi: https://doi.org/10.1101/2021.05.10.21256920; this version posted May 11, 2021. The copyright holder for this preprint (which was not certified by peer review) is the author/funder, who has granted medRxiv a license to display the preprint in perpetuity.

It is made available under a CC-BY-NC 4.0 International license .

There were two studies of young adults. One included 2,345 Swiss men (mean age 29 years), ${ }^{43}$ and the other assessed 3,563 to 3,694 adult twins aged approximately 23 to 26 years. ${ }^{44}$

Among studies of children and adolescents, one study from China included 1,241 children in grades 4 to $8 .{ }^{48}$ The other 3 studies, from the Netherlands, ${ }^{45}$ Spain, ${ }^{46}$ and Australia, ${ }^{47}$ included 151 to 248 children or adolescents. The study from the Netherlands also reported results for parents $(\mathrm{N}=106){ }^{45}$

There were 10 studies of university students, including 4 from China, ${ }^{49,53,54,55} 2$ from the United States, ${ }^{52,58}$ and 1 each from Switzerland, ${ }^{50}$ Canada, ${ }^{51}$ India, ${ }^{56}$ and the United Kingdom; ${ }^{57}$ all were convenience samples or were not well-described but appeared to be convenience samples. Two studies from China ${ }^{49,54}$ analysed data from 2,603 and 4,341 participants, two other studies ${ }^{51,53}$ evaluated between 555 and 733 participants, and the other 6 studies ${ }^{50,52,55-58}$ had 217 or fewer participants.

There were 5 studies of people with pre-existing medical conditions. One study from the United States ${ }^{59}$ included 1,504 participants with rheumatic diseases, and a study from Hong Kong ${ }^{63}$ evaluated 583 participants. The other 3 studies $^{60-62}$ all included 435 participants or fewer. Additionally, a study from China assessed 385 physicians in training. ${ }^{64}$

There were two studies of sexual or gender minority individuals. One was a convenience sample of 2,288 participants with a range of gender identities from the United States, ${ }^{66}$ and the other was a study of 681 gay or bisexual men from Australia. ${ }^{65}$

\section{Adequacy of Study Methods and Reporting}

Ratings of adequacy of methods and reporting are shown in Table 2. The two large national probability-based cohorts from the United Kingdom ${ }^{30,34}$ and the Netherlands ${ }^{36,37}$ were rated "Yes" on all items ${ }^{36,37,41}$ or all but one item. ${ }^{30,34}$ Another large national study from China ${ }^{42}$ had access to pre-COVID-19 data from over 188,000 nationally representative older results, but the COVID-19 follow-up (rated "No") was essentially a convenience sample, as participants ( $\mathrm{N}=$ 
medRxiv preprint doi: https://doi.org/10.1101/2021.05.10.21256920; this version posted May 11, 2021. The copyright holder for this preprint (which was not certified by peer review) is the author/funder, who has granted medRxiv a license to display the preprint in perpetuity.

It is made available under a CC-BY-NC 4.0 International license .

$6,467)$ were recruited via a publicity campaign. There were also concerns about several other studies described as national samples related to sampling or follow-up, some of which were not reported adequately enough to assess..$^{38,39,43,44}$ Other included studies tended to be local, largely convenience samples.

Overall, among the 36 included studies, there were high proportions of studies with "No" or "Unclear" ratings for appropriate sampling frame (23 studies, 64\%), recruitment method (26 studies, 72\%), adequate response rate and coverage (30 studies, $83 \%$ ), and follow-up response rate and management (18 studies, 50\%). For participant and setting description, use of valid assessment methods (which was an inclusion requirement for our systematic review), standard outcome collection methods, and providing appropriately analysed results, proportions with "Yes" ratings were between $92 \%$ and $100 \%$.

\section{Changes in Mental Health Symptoms}

Changes in mental health symptoms are shown in Table 3 for general mental health, Table 4 for anxiety symptoms, and Table 5 for depression symptoms. All meta-analyses included continuous outcomes and data collected between March and June 2020.

\section{$\underline{\text { General Mental Health }}$}

We were able to synthesize results for 4 general population cohorts ( 6 studies), ${ }^{30,33-37} 4$ cohorts (7 studies) with data for older adults, ${ }^{30,34,36,37,39-41}$ and 3 studies of university students. ${ }^{53,54,57}$ In all 3 groups of studies, estimates of change were close to zero, including in the general population (Figure 2a), SMD = $0.02\left(95 \% \mathrm{Cl}-0.11\right.$ to $\left.0.16 ; \mathrm{N}=19,707 ; I^{2}=94.6 \%\right)$; older adults (Figure $2 b), S M D=0.02\left(95 \% C l-0.11\right.$ to $\left.0.16 ; N=5,520 ; I^{2}=90.4 \%\right)$; and university students (Figure $2 \mathrm{c}), \mathrm{SMD}=-0.01\left(95 \% \mathrm{Cl}-0.33\right.$ to $\left.0.30 ; \mathrm{N}=3,372 ; \mathrm{I}^{2}=92.0 \%\right)$. The only study that reported statistically significant worse general mental health, a nationally sampled study from the United Kingdom $\left(\mathrm{N}=15,376\right.$; $\mathrm{SMD}_{\text {difference }}=0.18,95 \% \mathrm{Cl} 0.16$ to 0.21 ; $\mathrm{SMD}_{\text {regression }}=0.08,95 \% \mathrm{Cl} 0.05$ to 010$),{ }^{30}$ also reported dichotomous data. ${ }^{34}$ Based on dichotomous data, there was an increase of $8.7 \%(95 \% \mathrm{Cl} 6.9 \%$ to $10.4 \%)$ of people with a 
medRxiv preprint doi: https://doi.org/10.1101/2021.05.10.21256920; this version posted May 11, 2021. The copyright holder for this preprint (which was not certified by peer review) is the author/funder, who has granted medRxiv a license to display the preprint in perpetuity.

It is made available under a CC-BY-NC 4.0 International license .

GHQ-12 score of 4 or higher in April 2020 compared to pre-COVID-19, but this dissipated by September $2020(0.0 \%, 95 \% \mathrm{Cl}-2.0 \%$ to $1.9 \%)$. Continuous data were only reported in April 2020.

Analyses of data from older adults, young adults, women or females, and men or males from the United Kingdom cohort, based on dichotomous data, suggested some worsening of general mental health in April 2020 with a return to pre-COVID-19 levels by September. ${ }^{30,34}$ The general population cohort from the Netherlands, on the other hand, did not identify substantive changes in mental health in either early or late $2020 . .^{36,37}$

\section{Anxiety Symptoms}

Estimates of changes in anxiety symptoms from pre-COVID-19 were close to zero and not statistically significant in 5 studies of university students ${ }^{50,51,55,56,58}$ (Figure 3a), SMD $=0.00$ (95\% Cl -0.35 to $0.36 ; N=1,537 ; I^{2}=95.4 \%$ ); 3 studies with data on women or females ${ }^{44,47,56}$ (Figure $3 b), \operatorname{SMD}=0.02\left(95 \% \mathrm{Cl}-0.35\right.$ to $\left.0.39 ; \mathrm{N}=2,778 ; \mathrm{I}^{2}=92.3 \%\right)$; and 3 studies with data for men or males ${ }^{44,47,56}$ (Figure 3c), SMD $=0.07\left(95 \% \mathrm{Cl}-0.01\right.$ to $\left.0.15 ; \mathrm{N}=1,250 ; \mathrm{I}^{2}=0.01 \%\right)$. There was a statistically significant increase in anxiety in 3 studies of people with pre-existing medical conditions with outcomes between March and June 2020 $0^{59-61}$ (Figure 3d), SMD = $0.27(95 \% \mathrm{CI}$ 0.01 to $\left.0.54 ; N=2,053 ; I^{2}=91.0 \%\right)$. One of the studies also provided anxiety results for October to November $2020 ;{ }^{61}$ when those data were included rather than the earlier data for that study, the difference was smaller but still statistically significant, SMD $=0.19(95 \% \mathrm{Cl} 0.06$ to $0.31 ; \mathrm{N}=$ 1,$\left.940 ; I^{2}=52.3 \%\right)$

In other population groups, two large studies of older adults $(\mathrm{N}=3,281, \mathrm{~N}=6,467)^{38,42}$ and a large study of young adults $(\mathrm{N}=3,563)^{44}$ reported small but statistically significant increases in anxiety symptoms. Two studies of children or adolescents $(N=248, N=1,241)^{47,48}$ did not find statistically significant differences from zero. Among studies of sexual or gender minority individuals, a study of 681 gay or bisexual men reported a change estimate close to 
medRxiv preprint doi: https://doi.org/10.1101/2021.05.10.21256920; this version posted May 11, 2021. The copyright holder for this preprint (which was not certified by peer review) is the author/funder, who has granted medRxiv a license to display the preprint in perpetuity. It is made available under a CC-BY-NC 4.0 International license .

zero, ${ }^{65}$ whereas a study of 2,288 people with multiple gender identities reported a large increase $(\mathrm{SMD}=0.54,95 \% \mathrm{Cl} 0.48$ to 0.60$) .{ }^{66}$

\section{Depression Symptoms}

Changes in depression symptoms were close to zero or small and not statistically significant in 4 meta-analyses, including 5 studies of university students ${ }^{50,51,55,56,58}$ (Figure 4a), SMD $=0.19\left(95 \% \mathrm{Cl}-0.08\right.$ to $\left.0.45 ; \mathrm{N}=1,537 ; \mathrm{I}^{2}=91.8 \%\right) ; 3$ studies of people with pre-existing medical conditions ${ }^{59-61}$ (Figure $\left.4 b\right), S M D=0.01\left(95 \% \mathrm{Cl}-0.06\right.$ to $\left.0.08 ; N=2,006 ; I^{2}=14.9 \%\right), 3$ studies on women or females ${ }^{44,47,56}$ (Figure $\left.4 \mathrm{c}\right), \mathrm{SMD}=0.21\left(95 \% \mathrm{Cl}-0.14\right.$ to $0.55 ; \mathrm{N}=2,843 ; \mathrm{I}^{2}$ $=91.2 \%)$; and 4 studies with men or males ${ }^{43,44,47,56}$ (Figure $\left.4 d\right), S M D=0.00(95 \% \mathrm{Cl}-0.21$ to $\left.0.22 ; N=3,661 ; I^{2}=92.3 \%\right)$. Results were similar for people with pre-existing medical conditions when data from October to November 2020 were used instead of data from earlier for one study ${ }^{61}$ (not shown).

In other groups, individual studies reported small statistically significant increases among older adults $(\mathrm{N}=3,281),{ }^{38}$ children and adolescents $(\mathrm{N}=248, \mathrm{~N}=1,241),{ }^{47,48}$ and sexual or gender minority individiuals. ${ }^{66}$ One study $(\mathrm{N}=2,345)^{43}$ reported a statistically significant, small, improvement among young adult men, and studies reported non-statistically significant findings in the general population $(\mathrm{N}=102, \mathrm{~N}=218),{ }^{32,35}$ among young adults $(\mathrm{N}=3,563),{ }^{44}$ and in a sample of gay and bisexual men $(\mathrm{N}=681) .{ }^{65}$

\section{DISCUSSION}

\section{Principal Findings}

We reviewed over 45,000 citations and included 36 studies from 33 cohorts that compared general mental health, anxiety symptoms, or depression symptoms during COVID-19 to assessments done prior to COVID-19. Included studies assessed mental health changes in the general population and among older adults, younger adults, children and adolescents, parents, university students, people with pre-existing medical conditions, medical staff, and sexual or gender minority individuals. All studies assessed COVID-19 symptoms between March and 
medRxiv preprint doi: https://doi.org/10.1101/2021.05.10.21256920; this version posted May 11, 2021. The copyright holder for this preprint (which was not certified by peer review) is the author/funder, who has granted medRxiv a license to display the preprint in perpetuity. It is made available under a CC-BY-NC 4.0 International license .

June 2020. Large population-based cohorts from the United Kingdom ${ }^{30,34}$ and the Netherlands ${ }^{36,37,41}$ and a cohort of people with the rare autoimmune disease systemic sclerosis from 4 countries $^{61}$ also assessed symptoms between September and November 2020.

The main finding was that there was little evidence that mental health symptoms have worsened on a population level during COVID-19. Among general population studies, there was no change in general mental health $(S M D=0.02,95 \% \mathrm{Cl}-0.11$ to $0.16 ; 4$ studies, $\mathrm{N}=19,707)$, and changes in anxiety and depression symptoms, which were reported in only two small studies, ${ }^{32,35}$ did not differ significantly from zero. Similarly, meta-analyses of general mental health in older adults ( 4 studies, $N=5,520$ ) and university students ( 3 studies, $N=3,372$ ); anxiety symptoms in university students ( 5 studies, $N=1,537$ ), women or females ( 3 studies, $N$ $=2,778$ ), and men or males ( 3 studies, $N=1,250$ ); and depression symptoms in university students ( 5 studies, $N=1,537$ ); people with pre-existing medical conditions ( 3 studies, $N=$ 2,006 ), women or females ( 3 studies, $N=2,843$ ), and men or males ( 3 studies, $N=3,661$ ) did not find that changes in mental health symptoms during COVID-19 differed substantively or statistically significantly from pre-COVID-19 levels.

There were exceptions. Among people with pre-existing medical conditions, symptoms of anxiety increased in March to June 2020 compared to pre-COVID-19 (SMD = 0.27, 95\% CI 0.01 to $0.54 ; 3$ studies, $\mathrm{N}=2$,053). Additionally, among groups where meta-analyses were not conducted, in one study of 2,288 gender-minority individuals, symptoms of anxiety increased by $\mathrm{SMD}=0.54(95 \% \mathrm{Cl} 0.48$ to 0.60$),{ }^{66}$ although another study of 681 gay and bisexual men did not find a difference $(\mathrm{SMD}=0.08,95 \% \mathrm{Cl}-0.02$ to 0.19$) .{ }^{65}$

There were 3 cohorts $^{30,34,36,37,41,61}$ that assessed changes in both March to June and September to November 2020. In a large Dutch general population sample ( $N=3,983$ to 4,064$)$, change in general mental health was close to zero at both time points, and this was also the case for subgroups..$^{36,37,41}$ In a United Kingdom general population study, there was a small

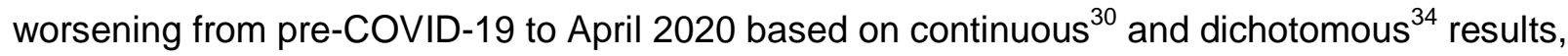


medRxiv preprint doi: https://doi.org/10.1101/2021.05.10.21256920; this version posted May 11, 2021. The copyright holder for this preprint (which was not certified by peer review) is the author/funder, who has granted medRxiv a license to display the preprint in perpetuity. It is made available under a CC-BY-NC 4.0 International license .

but dichotomous results from September 2020 were not different from pre-COVID-19. Similarly, in a cohort of people with systemic sclerosis, ${ }^{61}$ anxiety symptoms were substantially higher in April 2020 compared to pre-COVID-19 ( $N=435$; SMD = 0.51, 95\% Cl 0.37 to 0.64 ), but they were closer to pre-COVID-19 levels in October to November 2020 ( $N=322 ;$ SMD = 0.16, 95\% Cl 0.01 to 0.32$)$.

\section{Findings in Context}

The main finding that mental health does not appear to have worsened substantively in COVID-19 is consistent with analyses from other studies of mental health disorders and suicide. A study from Norway ${ }^{67}$ evaluated current mental disorders using the Composite International Diagnostic Interview (version 5.0) in a series of cross-sectional random samples accumulated from January 28 to March 11, 2020 ( $N=563,15.4 \%, 95 \%$ Cl 12.5\% to 18.8\%), March 12 to May 31, $2020(\mathrm{~N}=691,9.0 \%, 95 \% \mathrm{Cl} 7.1 \%$ to $11.4 \%)$, June 1 to July $31,2020(\mathrm{~N}=530$, $14.3 \%, 95 \% \mathrm{Cl} 11.5 \%$ to $17.5 \%$ ), and August 1 to September 18, 2020 ( $\mathrm{N}=370,11.9 \%, 95 \%$ Cl $9.0 \%$ to $15.6 \%$ ). The authors concluded that prevalence during COVID-19, compared to January to March 2020, which they considered pre-COVID-19, was stable or slightly decreased.

The authors of the largest study to date on suicide in COVID-1968 analysed data from official government sources on suicide occurences at a monthly level from January 1, 2019 or earlier to July 31,2020 . They used an interrupted time-series analysis to model trends in monthly suicides before COVID-19 (January 1, 2019 or earlier to March 31, 2020) and compared the expected number from the model with the observed number of suicides from April 1 to July 31,2020 for data from 21 countries. There was no evidence of a statistically significant increase in suicide risk in any country or area; there were, however, statistically significant decreases in 12 countries or areas.

Together, our findings on mental health symptoms, along with evidence on mental disorders and suicide, converge to suggest that COVID-19 mental health may be, at least up to now, a story of resilience rather than a mental health disaster, pandemic unto itself, or "tsunami" 
medRxiv preprint doi: https://doi.org/10.1101/2021.05.10.21256920; this version posted May 11, 2021. The copyright holder for this preprint (which was not certified by peer review) is the author/funder, who has granted medRxiv a license to display the preprint in perpetuity. It is made available under a CC-BY-NC 4.0 International license .

as has been described widely in the media. ${ }^{19}$ Short news cycles that emphasize dramatic events, anecdotes, and an uncritical reliance on unvalidated, difficult to interpret survey tools that inquire about mental health and well-being in COVID-19 among conveniently recruited volunteers might at least partially explain this discrepancy. Illustrating the pitfalls of interpreting studies that ask about COVID-19-specific angst, a study of 2,345 young men from Switzerland ${ }^{43}$ evaluated depression symptoms and stress during COVID-19 and found that they had significantly decreased compared to pre-pandemic levels. They also reported results from a series of unvalidated single items that queried about psychological status during COVID-19 and specifically assigned COVID-19 as the cause (e.g., "due to COVID-19, I experienced..."); these items suggested very high levels of distress, which became the focus of the study's conclusions. Together with the findings from our systematic review, this suggests that many or most people are likely experiencing different aspects of COVID-19 as highly unpleasant or distressing, but that most people have been resilient and that there is no evidence that population-level mental health has changed substantively.

\section{Policy Implications}

The lack of a decline in mental health so far in COVID-19 could be because people are resilient and have made the best of a difficult situation. Indeed, although evidence is thin in this area, there are data to suggest, for instance, that suicide has generally declined during periods of societal conflict. ${ }^{69-73}$ War and pandemics have very different characteristics, but in both there is a shared threat and common focus on collective action to address that threat.

The absence of evidence of substantive mental health decline could also reflect steps that governments around the world have taken to support mental health. The World Health Organization, other pan-national organizations, and governments across the globe have produced strategies for addressing mental health and have invested in resources to support public mental health, ${ }^{74,75}$ even in countries where mental health had not been a priority 
medRxiv preprint doi: https://doi.org/10.1101/2021.05.10.21256920; this version posted May 11, 2021. The copyright holder for this preprint (which was not certified by peer review) is the author/funder, who has granted medRxiv a license to display the preprint in perpetuity. It is made available under a CC-BY-NC 4.0 International license .

previously. ${ }^{76,77}$ It is not known to what degree these efforts have been effective, but it is possible that government action has played an important role.

\section{Strengths and Limitations}

Strengths of our systematic review include using rigorous best-practice methods; searching 9 databases, including 2 Chinese databases; not restricting inclusion by language; and the ability to update rapidly as evidence emerges via our living systematic review approach. There are also limitations that suggest some level of caution in interpreting results. First, aside from several population-level randomly sampled surveys, most of the studies included in our systematic review had limitations related to study sampling frames and recruitment methods, response and follow-up rates, and management of missing follow-up data. Second, heterogeneity was high in most of the meta-analyses that we conducted. Third, only a handful of studies reported results from the fall months of 2020, and, although the few studies that did suggested that symptoms were stable or reduced from earlier in the pandemic, more data are needed. Fourth, although we were able to synthesize results from several vulnerable groups, including older adults and people with pre-existing medical conditions, there were few studies with results for other vulnerable groups. It is possible that some groups may be experiencing important negative mental health effects of the pandemic and were not included in the studies we identified. Fifth, some potentially important outcomes, such as loneliness, were infrequently studied and not included in the present report. Sixth, the evidence base is rapidly evolving, and main results could change, although our living systematic review format will allow rapid updating as this occurs.

\section{Conclusions}

We reviewed 36 studies with data from 33 unique cohorts. Across population groups, results suggest that, rather than a mental health crisis, at a population level, there has been a high level of resilience during COVID-19 with minimal change in general mental health, anxiety symptoms, and depressive symptoms. There were few robust studies with vulnerable groups, 
medRxiv preprint doi: https://doi.org/10.1101/2021.05.10.21256920; this version posted May 11, 2021. The copyright holder for this preprint (which was not certified by peer review) is the author/funder, who has granted medRxiv a license to display the preprint in perpetuity. It is made available under a CC-BY-NC 4.0 International license.

however, and it is possible that there are population groups that are experiencing a different level of mental health effect than the general population or other groups. COVID-19 continues to affect societies across the world, and it will be important to continue to assess mental health as lockdown restrictions continue, even intermittently, and post-COVID-19, as COVID-19 mental health implications may persist beyond the pandemic. There do not appear to be substantial negative population-wide mental health effects at this point, but the pandemic has upended the lives of many people around the world, and there is little doubt that some people who have not experienced mental health difficulties previously are experiencing them now. Governments should continue to ensure that mental health supports are maximally available. 
medRxiv preprint doi: https://doi.org/10.1101/2021.05.10.21256920; this version posted May 11, 2021. The copyright holder for this preprint (which was not certified by peer review) is the author/funder, who has granted medRxiv a license to display the preprint in perpetuity. It is made available under a CC-BY-NC 4.0 International license.

\section{Contributions:}

YS, YWu, DBR, AB, and BDT were responsible for the study conception and design. JTB was responsible for the design of the database searches. AK carried out the searches. YS, YWu, OB, AK, CH, YWang, DBR, XJ, KL, SM, MA, ITV, DN, TDS, AT, AY, and BDT contributed to data extraction, coding, and evaluation of included studies. $\mathrm{OB}, \mathrm{CH}$, and $\mathrm{YS}$ were responsible for study coordination. YS, YWu, BL, AB, and BDT were involved in data analysis. BA, CF, MSM, SS, and GT contributed to interpretation of results as knowledge translation partners. YS and BDT drafted the manuscript. All authors provided a critical review and approved the final manuscript. BDT is the guarantor; he had full access to all the data in the study and takes responsibility for the integrity of the data and the accuracy of the data analyses. BDT is the corresponding author and attests that all listed authors meet authorship criteria and that no others meeting the criteria have been omitted.

\section{Copyright for Authors:}

The Corresponding Author has the right to grant on behalf of all authors and does grant on behalf of all authors, a worldwide licence to the Publishers and its licensees in perpetuity, in all forms, formats and media (whether known now or created in the future), to i) publish, reproduce, distribute, display and store the Contribution, ii) translate the Contribution into other languages, create adaptations, reprints, include within collections and create summaries, extracts and/or, abstracts of the Contribution, iii) create any other derivative work(s) based on the Contribution, iv) to exploit all subsidiary rights in the Contribution, v) the inclusion of electronic links from the Contribution to third party material where-ever it may be located; and, vi) licence any third party to do any or all of the above.

The Corresponding Author has the right to grant on behalf of all authors and does grant on behalf of all authors, an exclusive licence (or non-exclusive for government employees) on a 
medRxiv preprint doi: https://doi.org/10.1101/2021.05.10.21256920; this version posted May 11, 2021. The copyright holder for this preprint (which was not certified by peer review) is the author/funder, who has granted medRxiv a license to display the preprint in perpetuity. It is made available under a CC-BY-NC 4.0 International license .

worldwide basis to the BMJ Publishing Group Ltd to permit this article (if accepted) to be published in BMJ editions and any other BMJPGL products and sublicences such use and exploit all subsidiary rights, as set out in our licence.

\section{Funding:}

The study was funded by the Canadian Institutes of Health Research (CMS-171703; MS1173070) and McGill Interdisciplinary Initiative in Infection and Immunity Emergency COVID-19 Research Fund (R2-42). YWu and BL were supported by a Fonds de recherche du Québec Santé (FRQS) Postdoctoral Training Fellowship. DBR was supported by a Vanier Canada Graduate Scholarship. AB was supported by FRQS senior researcher salary awards. BDT was supported by a Tier 1 Canada Research Chair.

\section{Declaration of Competing Interests:}

All authors have completed the ICJME uniform disclosure form at www.icmje.org/coi_disclosure.pdf and declare: no support from any organisation for the submitted work; no financial relationships with any organisations that might have an interest in the submitted work in the previous three years. All authors declare no relationships or activities that could appear to have influenced the submitted work. No funder had any role in the design and conduct of the study; collection, management, analysis, and interpretation of the data; preparation, review, or approval of the manuscript; and decision to submit the manuscript for publication. BDT and AB declared that they were authors of an included study. ${ }^{61}$

\section{Ethical Approval:}

As this study was a systematic review of published results, it did not require ethical approval. 


\section{Transparency Declaration:}

The manuscript's guarantor affirms that the manuscript is an honest, accurate, and transparent account of the study being reported; that no important aspects of the study have been omitted; and that any discrepancies from the study as planned (and, if relevant, registered) have been explained.

\section{Data Sharing:}

All data used in the study are available in the manuscript and its tables or on online at https://www.depressd.ca/covid-19-mental-health.

\section{Dissemination to study participants or patient communities:}

There are no plans to disseminate the results of the research directly to a relevant patient community. However, all study results are available at https://www.depressd.ca/researchquestion-1-symptom-changes.

\section{Provenance and peer review:}

Not commissioned; externally peer reviewed.

\section{BY licence:}

The default licence, a CC BY NC licence, is needed. 
What is already known on this topic:

- $\quad$ Large numbers of studies and media reports have concluded that COVID-19 has led to widespread decline in population mental health.

- $\quad$ Existing evidence reviews have been based on cross-sectional studies and conclusions based on proportions of study respondents above thresholds on mental health measures, which are not intended for this purpose and can be highly misleading.

\section{What this study adds:}

- We synthesized evidence from 36 studies that compared general mental health, anxiety symptoms, or depression symptoms during COVID-19 to outcomes prior to COVID-19 in the same participant cohort.

- Mental health in the general population has not worsened compared to pre-COVID-19 levels.

- $\quad$ Among other populations, anxiety among people with pre-existing medical conditions appears to have increased early in the pandemic, although it may have improved in later months; there were no indications of negative changes in other populations for any other outcomes. 
medRxiv preprint doi: https://doi.org/10.1101/2021.05.10.21256920; this version posted May 11, 2021. The copyright holder for this preprint

(which was not certified by peer review) is the author/funder, who has granted medRxiv a license to display the preprint in perpetuity.

It is made available under a CC-BY-NC 4.0 International license .

\section{REFERENCES}

1. World Health Organization. WHO Coronavirus Disease (COVID-19) Dashboard. https://covid19.who.int/. Accessed May 10, 2021.

2. World Health Organization. Impact of COVID-19 on people's livelihoods, their health and our food systems: joint statement by ILO, FAO, IFAD and WHO.

https://www.who.int/news/item/13-10-2020-impact-of-covid-19-on-people\%27s-livelihoodstheir-health-and-our-food-systems. Accessed May 10, 2021.

3. Rubin GJ, Wessely S. The psychological effects of quarantining a city. BMJ 2020;368:m313.

4. Living systematic review of mental health in COVID-19. https://www.depressd.ca/covid-19mental-health. Accessed May 10, 2021.

5. Glasziou P, Sanders S, Hoffmann T. Waste in covid-19 research. BMJ 2020;369:m1847

6. Thombs BD, Kwakkenbos L, Levis AW, et al. Addressing overestimation of the prevalence of depression based on self-report screening questionnaires. CMAJ 2018;190:E44-E49.

7. Levis B, Yan XW, He C, et al. Comparison of depression prevalence estimates in metaanalyses based on screening tools and rating scales versus diagnostic interviews: a metaresearch review. BMC Med 2019;17:65.

8. Levis B, Benedetti A, loannidis JPA, et al. Patient Health Questionnaire-9 scores do not accurately estimate depression prevalence: individual participant data meta-analysis. J Clin Epidemiol 2020;122:115-128.

9. Lyubenova A, Neupane D, Levis B, et al. Depression prevalence based on the Edinburgh Postnatal Depression Scale compared to Structured Clinical Interview for DSM Disorders classification: Systematic review and individual participant data meta-analysis. Int $J$ Methods Psychiatr Res 2021;30:e1860. 
medRxiv preprint doi: https://doi.org/10.1101/2021.05.10.21256920; this version posted May 11, 2021. The copyright holder for this preprint

(which was not certified by peer review) is the author/funder, who has granted medRxiv a license to display the preprint in perpetuity.

It is made available under a CC-BY-NC 4.0 International license .

10. Brehaut E, Neupane D, Levis B, et al. Depression prevalence using the HADS-D compared to SCID major depression classification: An individual participant data meta-analysis. J Psychosom Res 2020;139:110256.

11. Kroenke K, Spitzer RL, Williams JB. The PHQ-9: validity of a brief depression severity measure. J Gen Intern Med 2001;16:606-613.

12. Yu X, Tam WWS, Wong PTK, et al. The Patient Health Questionnaire-9 for measuring depressive symptoms among the general population in Hong Kong. Compr Psychiatry 2012;53:95-102.

13. Kocalevent RD, Hinz A, Brähler E. Standardization of the depression screener Patient Health Questionnaire (PHQ-9) in the general population. Gen Hosp Psychiatry 2013;35:551-555.

14. Wang W, Bian Q, Zhao Y, et al. Reliability and validity of the Chinese version of the Patient Health Questionnaire (PHQ-9) in the general population. Gen Hosp Psychiatry $2014 ; 36: 539-544$.

15. Cao C, Hu L, Xu T, et al. Prevalence, correlates, and misperception of depression symptoms in the United States, NHANES 2015-2018. J Affect Disord 2020;269:51-57.

16. Patten SB, Schopflocher D. Longitudinal epidemiology of major depression as assessed by the Brief Patient Health Questionnaire (PHQ-9). Compr Psychiatry 2009;50:26-33.

17. Johansson R, Carlbring P, Heedman A, et al. Depression, anxiety and their comorbidity in the Swedish general population: point prevalence and the effect on health-related quality of life. PeerJ 2013;1:e98.

18. Lu S, Reavley N, Zhou J, et al. Depression among the general adult population in Jiangsu Province of China: prevalence, associated factors and impacts. Soc Psychiatry Psychiatr Epidemiol 2018;53:1051-1061.

19. Bentall R. Has the pandemic really caused a 'tsunami' of mental health problems? The Guardian. February 9, 2021. 
medRxiv preprint doi: https://doi.org/10.1101/2021.05.10.21256920; this version posted May 11, 2021. The copyright holder for this preprint

(which was not certified by peer review) is the author/funder, who has granted medRxiv a license to display the preprint in perpetuity.

It is made available under a CC-BY-NC 4.0 International license .

https://www.theguardian.com/commentisfree/2021/feb/09/pandemic-mental-health-

problems-research-coronavirus. Accessed May 10, 2021.

20. Elliott JH, Synnot A, Turner T, et al. Living systematic review: 1. Introduction - the why, what, when, and how. J Clin Epidemiol 2017;91:23-30.

21. Thombs BD, Bonardi O, Rice DB, et al. Curating evidence on mental health during COVID19: a living systematic review. J Psychosom Res 2020;133;110113.

22. Thombs BD, Bonardi O, Rice DB, et al. Mental health during the COVID-19 pandemic: protocol for a living systematic review of symptom levels, factors associated with symptoms, and intervention effectiveness. OSF 2020. Available from https://osf.io/96csg/.

23. Page MJ, McKenzie JE, Bossuyt PM, et al. The PRISMA 2020 statement: an updated guideline for reporting systematic reviews. BMJ 2021;372:n71.

24. World Health Organization. Rolling updates on coronavirus disease (COVID-19) 2020. https://www.who.int/emergencies/diseases/novel-coronavirus-2019/events-as-they-happen. Accessed May 10, 2021.

25. Joanna Briggs Institute. The Joanna Briggs Institute Critical Appraisal tools for use in JBI Systematic Reviews: Checklist for Prevalence Studies. https://jbi.global/critical-appraisaltools. Accessed May 10, 2021.

26. Hedges LV. Estimation of effect size from a series of independent experiments. Psychol Bull 1982;92:490-499.

27. Borenstein M, Hedges LV, Higgins JPT, Rothstein HR. Chapter 4: Effect sizes based on means. In Borenstein M, Hedges LV, Higgins JPT, Rothstein HR (editors). Introduction to meta-analysis. Wiley \& Sons: West Sussex, UK. 2009.

28. Agresti A, Coull BA. Approximate is better than "exact" for interval estimation of binomial proportions. Am Stat 1998;52:119-26.

29. Newcombe RG. Improved confidence intervals for the difference between binomial proportions based on paired data. Stat Med 1998;17:2635-2650. 
medRxiv preprint doi: https://doi.org/10.1101/2021.05.10.21256920; this version posted May 11, 2021. The copyright holder for this preprint

(which was not certified by peer review) is the author/funder, who has granted medRxiv a license to display the preprint in perpetuity.

It is made available under a CC-BY-NC 4.0 International license .

30. Pierce M, Hope H, Ford T, et al. Mental health before and during the COVID-19 pandemic: a longitudinal probability sample survey of the UK population. Lancet Psychiatry 2020;7:883-92.

31. Viechtbauer W. Conducting meta-analyses in R with the metafor package. J Stat Softw 2010;36:1-48.

32. Benz A, Meier M, Bentele UU, et al. Early life adversity, dispositional mindfulness, and longitudinal stress experience during the COVID-19 pandemic. PsyArXiv 2020. https://doi.org/10.31234/osf.io/5kt6z.

33. Castellini G, Rossi E, Cassioli E, et al. A longitudinal observation of general psychopathology before the COVID-19 outbreak and during lockdown in Italy. J Psychosom Res 2021;141:110328.

34. Daly M, Robinson E. Longitudinal changes in psychological distress in the UK from 2019 to September 2020 during the COVID-19 pandemic: Evidence from a large nationally representative study. Psychiatry Res 2021;300:113920.

35. Katz B, Yovel I. Mood Symptoms Predict COVID-19 Pandemic Distress but not vice versa: An 18-Month Longitudinal Study. PsyArXiv 2020. https://doi.org/10.31234/osf.io/6qske.

36. van der Velden PG, Contino C, Das M, van Loon P, Bosmans MW. Anxiety and depression symptoms, and lack of emotional support among the general population before and during the COVID-19 pandemic. A prospective national study on prevalence and risk factors. $J$ Affect Disord 2020;277:540-8.

37. van der Velden PG, Marchand M, Das M, Muffels R, Bosmans M. The prevalence, incidence and risk factors of mental health problems and mental health services use before and 9 months after the COVID-19 outbreak among the general Dutch population. A 3-wave prospective study. MedRxiv 2021. https://doi.org/10.1101/2021.02.27.21251952।. 
medRxiv preprint doi: https://doi.org/10.1101/2021.05.10.21256920; this version posted May 11, 2021. The copyright holder for this preprint

(which was not certified by peer review) is the author/funder, who has granted medRxiv a license to display the preprint in perpetuity.

It is made available under a CC-BY-NC 4.0 International license .

38. Creese B, Khan Z, Henley W, et al. Loneliness, physical activity and mental health during Covid-19: a longitudinal analysis of depression and anxiety between 2015 and 2020. Int Psychogeriatr 2020. https://doi.org/10.1017/S1041610220004135.

39. Kivi M, Hansson I, Bjälkebring P. Up and about: Older adults' well-being during the COVID19 pandemic in a Swedish longitudinal study. J Gerontol 2021;76:e4-9.

40. Okely JA, Corley J, Welstead M, et al. Change in Physical Activity, Sleep Quality, and Psychosocial Variables during COVID-19 Lockdown: Evidence from the Lothian Birth Cohort 1936. Int J Environ Res Public Health 2021;18:210.

41. Van Tilburg TG, Steinmetz S, Stolte E, van der Roest H, de Vries DH. Loneliness and mental health during the COVID-19 pandemic: A study among Dutch older adults. $J$ Gerontol 2020. https://doi.org/10.1093/geronb/gbaa111.

42. Wang ZH, Qi SG, Zhang H. 新型冠状病毒肺炎对社区老年人焦虑症状的影响 [Impact of the COVID?19 epidemic on anxiety among the elderly in community] Natl Med J China 2020;100:3179-85.

43. Marmet S, Wicki M, Gmel G, et al. The psychological impact of the COVID-19 crisis on young Swiss men participating in a cohort study. PsyArXiv 2020. Preprint. https://doi.org/10.31234/osf.io/kwxhd.

44. Rimfeld K, Malanchini M, Allegrini AG, et al. Genetic correlates of psychological responses to the COVID-19 crisis in young adult twins in Great Britain. Behav Genet 2021;51:110-24.

45. Achterberg M, Dobbelaar S, Boer OD, Crone E. Perceived stress as mediator for longitudinal effects of the COVID-19 lockdown on wellbeing of parents and children. Sci Rep 2021;11:2971.

46. Ezpeleta L, Navarro JB, de la Osa N, Trepat E, Penelo E. Life conditions during COVID-19 lockdown and mental health in Spanish adolescents. Int J Environ Res Public Health 2020;17:7327. 
medRxiv preprint doi: https://doi.org/10.1101/2021.05.10.21256920; this version posted May 11, 2021. The copyright holder for this preprint

(which was not certified by peer review) is the author/funder, who has granted medRxiv a license to display the preprint in perpetuity.

It is made available under a CC-BY-NC 4.0 International license .

47. Magson NR, Freeman JY, Rapee RM, Richardson CE, Oar EL, Fardouly J. Risk and protective factors for prospective changes in adolescent mental health during the COVID-19 pandemic. J Youth Adolesc 2021;50:44-57.

48. Zhang L, Zhang D, Fang J, Wan Y, Tao F, Sun Y. Assessment of mental health of Chinese primary school students before and after school closing and opening during the COVID-19 pandemic. JAMA Netw Open 2020;3:e2021482.

49. Dong XL. 新型冠状病毒肺炎疫情对师范类大学生心理健康的影响研究 [Influence study of COVID-2019 on mental health of normal college students] PSY 2020. https://www.doi.org/10.19738/j.cnki.psy.2020.20.013.

50. Elmer T, Mepham E, Stadtfeld C. Students under lockdown: Comparison of students' social networks and mental health before and during the COVID-19 crisis in Switzerland. PLoS ONE 2020;15:e0236337.

51. Hamza CA, Ewing L, Heath NL, Goldstein AL. When social isolation is nothing new: A longitudinal study psychological distress during COVID-19 among university students with and without preexisting mental health concerns. Can Psychol 2021;62:20-30.

52. Huckins J, da Silva A, Wang W, et al. Mental health and behaviour of college students during the early phases of the COVID-19 pandemic: Iongitudinal smartphone and ecological momentary assessment study. J Med Internet Res 2020;22:e20185.

53. Li HY, Cao H, Leung DY, Mak YW. The psychological impacts of a COVID-19 outbreak on college students in China: a longitudinal study. Int $J$ Environ Res Public Health 2020;17:3933.

54. Li RL, Dai J, Yuan XY, Li L. 新冠肺炎疫情期大学生心理健康状况 [Mental health of college students during COVID-19] J Panzhihua University 2020;37:18-24 
medRxiv preprint doi: https://doi.org/10.1101/2021.05.10.21256920; this version posted May 11, 2021. The copyright holder for this preprint

(which was not certified by peer review) is the author/funder, who has granted medRxiv a license to display the preprint in perpetuity.

It is made available under a CC-BY-NC 4.0 International license .

55. Li WW, Yu H, Miller DJ, Yang F, Rouen C. Novelty seeking and mental health in Chinese university students before, during, and after the COVID-19 pandemic lockdown: a longitudinal study. Front Psychol 2020. https://doi.org/10.3389/fpsyg.2020.600739.

56. Saraswathi I, Saikarthik J, Kumar KS, Srinivasan KM, Ardhanaari M, Gunapriya R. Impact of COVID-19 outbreak on the mental health status of undergraduate medical students in a COVID-19 treating medical college: a prospective longitudinal study. PeerJ 2020;8:e10164.

57. Savage MJ, James R, Magistro D, et al. Mental health and movement behaviour during the COVID-19 pandemic in UK university students: Prospective cohort study. Ment Health Phys Act 2020;19:100357.

58. Zimmermann M, Bledsoe C, Papa A. The impact of the COVID-19 pandemic on college student mental health: A longitudinal examination of risk and protective factors. PsyArXiv 2020. https://doi.org/10.31234/osf.io/2y7hu.

59. Katz P, Pedro S, Wipfler K, et al. Changes in Mental Health During the COVID-19 Pandemic Among Individuals with Rheumatic Disease. Arthritis Rheumatol 2020;72 (suppl 10). https://acrabstracts.org/abstract/changes-in-mental-healthduring-the-covid-19pandemic-among-individuals-with-rheumatic-disease/.

60. Liang JQ, Li XQ, Zhang WL, et al. 新冠肺炎流行期住院集中医学观察期间血液透析患者的焦 虑抑郁状况 [Anxiety and depression in patients with maintenance hemodialysis under concentrated medical observation in hospital during the COVID-19 epidemic] Chinese Mental Health Journal 2020. https://www.doi.org/10.3969/j.isn.10-6729.2020.12.014.

61. Thombs BD, Kwakkenbos L, Henry RS, et al. Comparison of mental health symptoms prior to and during COVID-19 among patients with systemic sclerosis from four countries: a Scleroderma Patient-centered Intervention Network (SPIN) Cohort study. J Psychosom Res 2020;139:110262. 
medRxiv preprint doi: https://doi.org/10.1101/2021.05.10.21256920; this version posted May 11, 2021. The copyright holder for this preprint

(which was not certified by peer review) is the author/funder, who has granted medRxiv a license to display the preprint in perpetuity.

It is made available under a CC-BY-NC 4.0 International license .

62. Ubara A, Sumi $\mathrm{Y}$, Ito $\mathrm{K}$, et al. Self-isolation due to CoViD-19 is linked to small one-year changes in depression, sleepiness, and insomnia: results from a clinic for sleep disorders in Shiga Prefecture, Japan. Int J Environ Res Public Health 2020;17:8971.

63. Wong SY, Zhang D, Sit RW, et al. Impact of COVID-19 on loneliness, mental health, and health service utilisation: a prospective cohort study of older adults with multimorbidity in primary care. Br J Gen Pract 2020;70:e817-24.

64. Li W, Frank E, Zhao Z, et al. Mental health of young physicians in China during the novel coronavirus disease 2019 outbreak. JAMA Netw Open 2020;3:e2010705.

65. Bavinton BR, Hammoud MA, Chan C, et al. Depression and Anxiety in Australian Gay and Bisexual Men Prior to and During Covid-19 Restrictions. Sexual Health 2020;17:XVIII.

66. Flentje A, Obedin-Maliver J, Lubensky ME, Dastur Z, Neilands T, Lunn MR. Depression and anxiety changes among sexual and gender minority people coinciding with onset of COVID19 pandemic. J Gen Intern Med 2020;35:2788-90.

67. Knudsen AK, Stene-Larsen K, Gustavson K, et al. Prevalence of mental disorders, suicidal ideation and suicides in the general population before and during the COVID-19 pandemic in Norway: A population-based repeated cross-sectional analysis. Lancet Reg Health $2021 ; 4: 100071$.

68. Pirkis J, John A, Shin S, et al. Suicide trends in the early months of the COVID-19 pandemic: an interrupted time-series analysis of preliminary data from 21 countries. Lancet Psychiatry 2021. https://doi.org/10.1016/S2215-0366(21)00091-2.

69. Lester D. The effect of war on suicide rates. A study of France from 1826 to 1913. Euro Arch Psychiatry Clin Neurosci 1993;242:248-9.

70. Lester D. Suicide rates before, during and after the world wars. Eur Psychiatry 19949:262264.

71. Somasundaraam DJ, Rajadurai S: War and suicide in northern Sri Lanka. Acta Psychiatr Scand 1995;91:1-4. 
medRxiv preprint doi: https://doi.org/10.1101/2021.05.10.21256920; this version posted May 11, 2021. The copyright holder for this preprint

(which was not certified by peer review) is the author/funder, who has granted medRxiv a license to display the preprint in perpetuity.

It is made available under a CC-BY-NC 4.0 International license .

72. Aida T. Revisiting suicide rate during wartime: Evidence from the Sri Lankan civil war. PLoS One 2020;15:e0240487.

73. Marshall JR. Political integration and the role of war in suicide. Soc Forces 1981;59:771785.

74. McMartan C, Adell T, Cameron J, et al. A scoping review of international policy responses to mental health recovery during the COVID-19 pandemic. Health Res Policy Syst $2021 ; 19: 58$.

75. Arendt F, Markiewitz A, Mestas M, Scherr S. COVID-19 pandemic, government responses, and public mental health: Investigating consequences through crisis hotline calls in two countries. Soc Sci Med 2020;265:113532.

76. Ju Y, Zhang Y, Wang X, Li W, Ng RMK, Li L. China's mental health support in response to COVID-19: progression, challenges and reflection. Global Health 2020;16:102.

77. Wang V, Hernández JC. China long avoided discussing mental health. The pandemic changed that. New York Times. December 21, 2020.

https://www.nytimes.com/2020/12/21/world/asia/china-covid-mental-health.html. Accessed May 10, 2021. 
medRxiv preprint doi: https://doi.org/10.1101/2021.05.10.21256920; this version posted May 11, 2021. The copyright holder for this preprint (which was not certified by peer review) is the author/funder, who has granted medRxiv a license to display the preprint in perpetuity. It is made available under a CC-BY-NC 4.0 International license .

\section{Box 1. Interpreting SMD Effect Sizes and Changes in Proportion Above a Threshold on Mental Health Measures}

Symptom changes assessed with mental health patient-reported outcome measures in COVID-19 have been reported as changes in continuous scores and the proportion of study participants above a threshold. Continuously measured symptom changes are presented in terms of SMDs, which describe change in terms of within-group standard deviations, rather than raw change scores, which are measure-specific and not easily compared across measures. To illustrate, Box 1 - Figure 1 illustrates the amount of change, assuming a normal distribution, for SMD $=0.25$. The hypothetical blue distribution represents pre-COVID-19 scores, and the grey distribution represents post-COVID-19 scores with a mean symptom increase of SMD $=0.25$.

When studies report an increase or decrease in the proportion of participants above a measure threshold, dichotomous thresholds used for this purpose are sometimes labelled as thresholds for "clinically significant" symptoms or as reflecting the presence of a condition (e.g., depression). ${ }^{6}$ These designations, are not, however, based on evidence that a threshold represents a meaningful divide between impairment and non-impairment and do not reflect the presence of a mental disorder. Most commonly, they reflect a point on a measure that balances sensitivity and specificity when used for screening, which does not inform when score levels might become clinically meaningful. ${ }^{6-10}$

Thresholds on different symptom measures are often located at different places in the symptom distribution. This can lead to divergent estimates of proportions crossing a threshold, depending on the measure used, rather than because of actual differences in symptom changes. As shown in Box 1 - Figure 1, the same change in symptoms in a hypothetical study sample would result in a $7 \%$ increase in participants at or above the threshold on one measure (black line, one standard deviation above pre-COVID-19 distribution mean) but an increase of only $2 \%$ on another (red line, two standard deviations above pre-COVID-19 distribution mean). 
medRxiv preprint doi: https://doi.org/10.1101/2021.05.10.21256920; this version posted May 11, 2021. The copyright holder for this preprint (which was not certified by peer review) is the author/funder, who has granted medRxiv a license to display the preprint in perpetuity. It is made available under a CC-BY-NC 4.0 International license .

We have prioritized interpretation of continuous score changes. We have also reported proportions above thresholds, as they can be informative, such as when they are reported for two time points in the same study or as an indicator if some level of change may have occurred. We have, however, avoided interpretation of the magnitudes of proportions above thresholds. 
medRxiv preprint doi: https://doi.org/10.1101/2021.05.10.21256920; this version posted May 11, 2021. The copyright holder for this preprint (which was not certified by peer review) is the author/funder, who has granted medRxiv a license to display the preprint in perpetuity. It is made available under a CC-BY-NC 4.0 International license .

\section{FIGURE LEGENDS}

Box 1 - Figure 1. Illustration of change of 0.25 standardized mean difference effect size from hypothetical pre-COVID-19 (blue) to COVID-19 (black) symptom distributions. With a threshold located at one standard deviation above the pre-COVID-19 mean, the proportion of participants above the threshold would change from $16 \%$ to $23 \%$. With a threshold two standard deviations above the pre-COVID-19 mean, the proportion would change from $2 \%$ to $4 \%$.

Figure 1. PRISMA flow diagram.

Figures 2a-2c. Forest plots of standardized mean difference changes in general mental health for studies of the general population (2a), older adults (2b), and university students (2c).

Figures 3a-3d. Forest plots of standardized mean difference changes in anxiety symptoms for studies of university students (3a), women or females (3b), men or males (3c), and people with pre-existing medical conditions $(3 d)$.

Figures 4a-4d. Forest plots of standardized mean difference changes in depression symptoms for studies of university students (4a), people with pre-existing medical conditions (4b), women or females (4c), and men or males (4d). 
Table 1. Characteristics of included studies $(\mathrm{N}=36)$

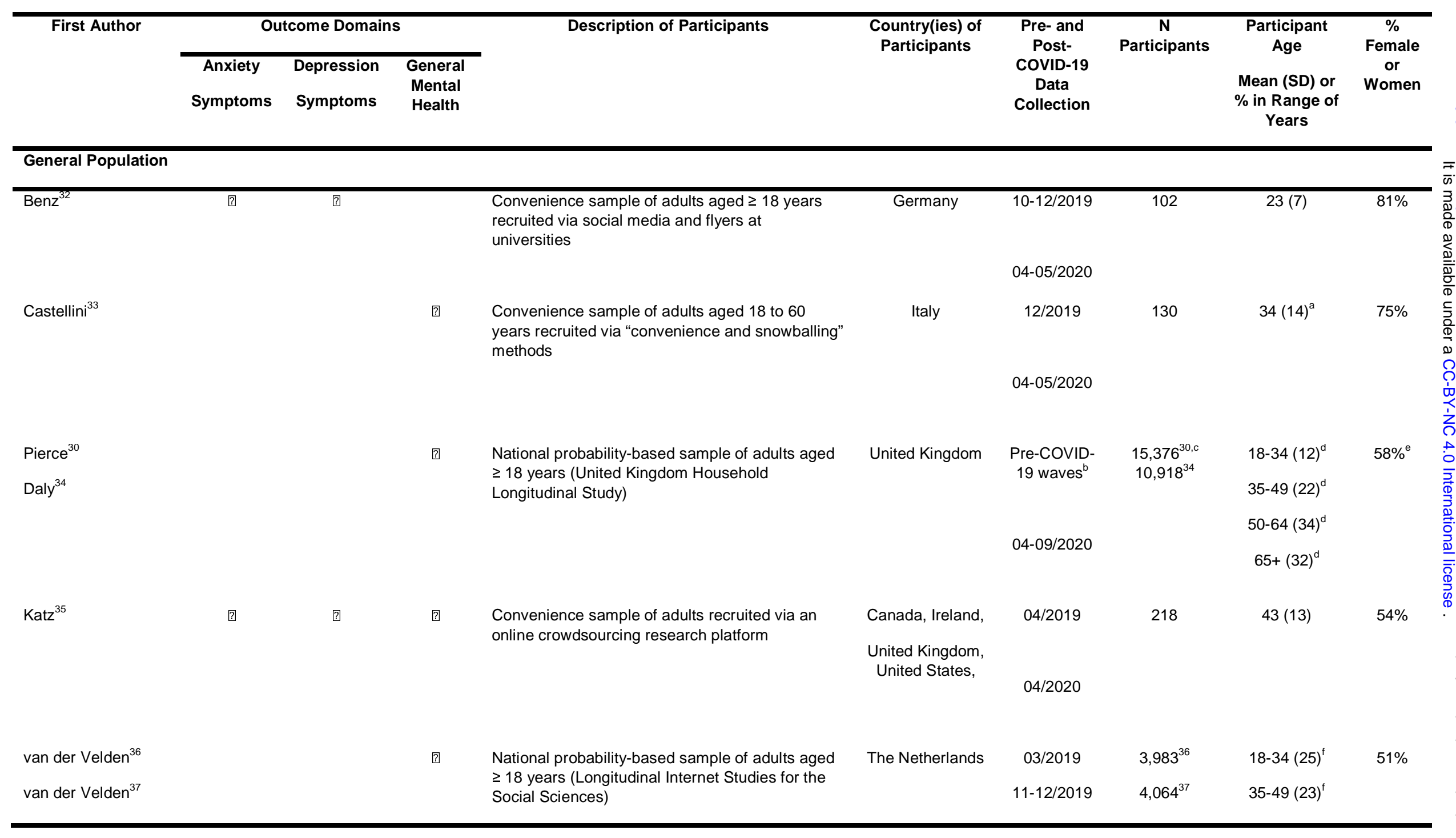


$11-12 / 2020$

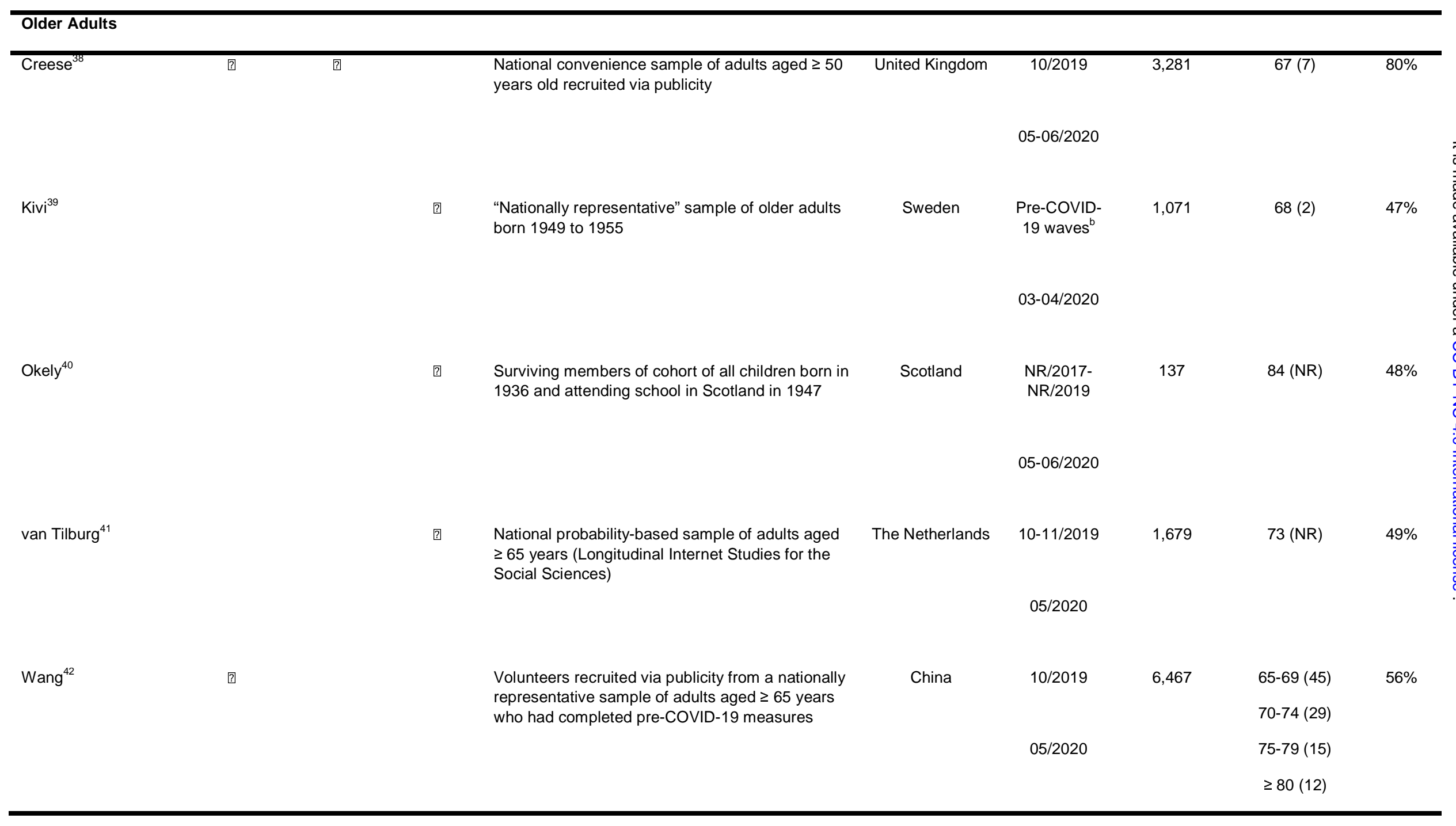




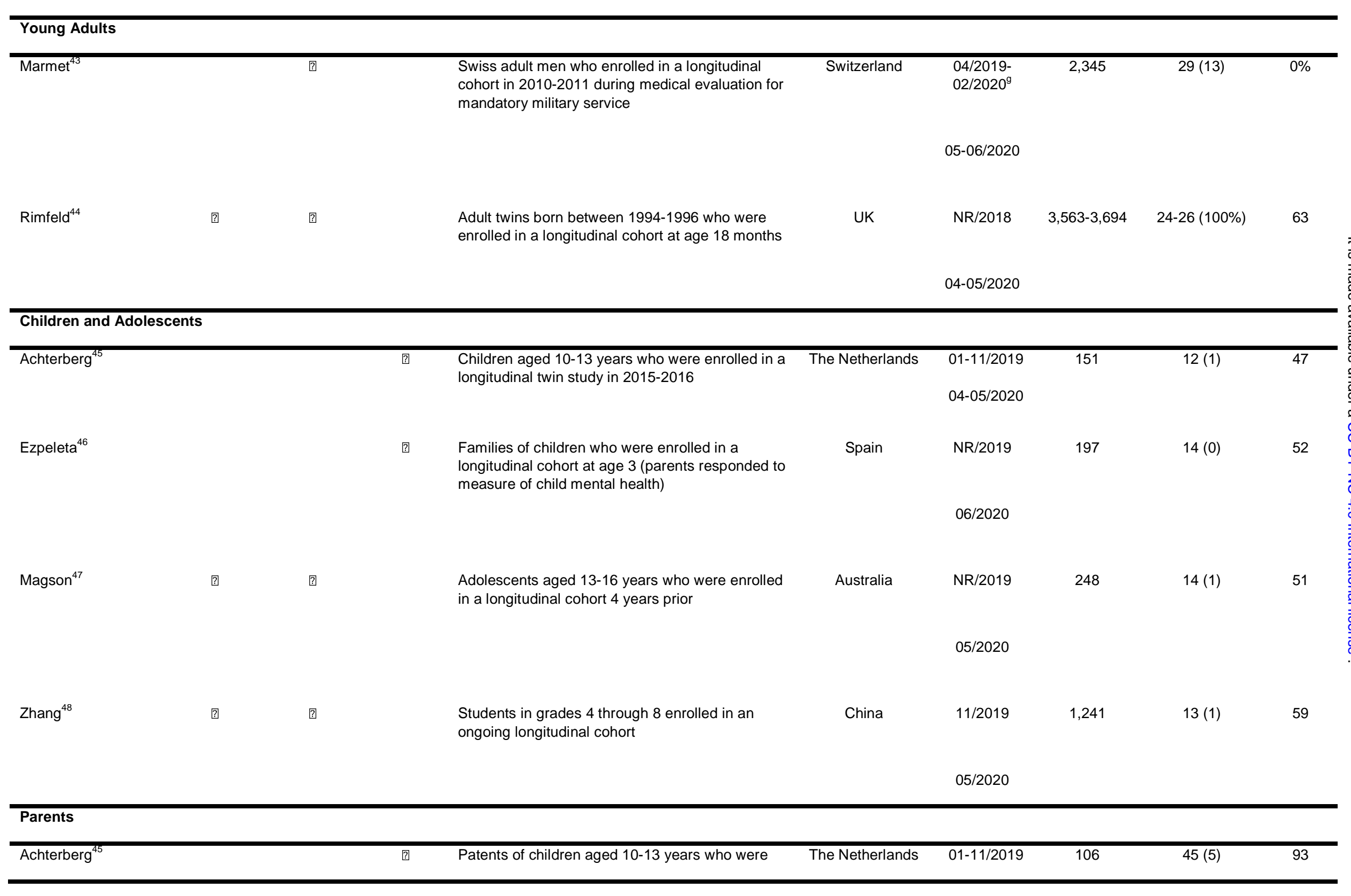




\section{University Students}

$N R / 2020$

Elmer $^{50}$

군

Huckins $^{52}$

Hamza $^{51}$

[?
$\mathrm{Li}$, Hongyan ${ }^{53}$

$\mathrm{Li}$, Renli ${ }^{54}$
Undergraduate students in engineering and natural sciences from a single university recruited by email invitation

Undergraduate students from single university recruited by email invitation

\section{Canada}

Switzerland

$09 / 2019$

209

$04 / 2020$

$05 / 2019$

733

$05 / 2020$

Undergraduate students from single university recruited by email invitation and enrolled in an ongoing longitudinal study

United States

Pre-COVID 19 waves $^{\text {b }}$

178

$03 / 2020$

Undergraduate students from a single university enrolled in an ongoing longitudinal study

China

$12 / 2019$

555

$04 / 2020$

$09 / 2019$

2,603

China

Undergraduate students from multiple
in Szechuan province recruited online 
Undergraduate students from single university

United Kingdom

$10 / 2019$

214

$18-21(64)$ recruited by email invitation
ongoing longitudinal study

$04 / 2020$

$$
\text { 26-35 (8) }
$$

Undergraduate students at a single university

United States

$08 / 2019$

205

$18(1)$

$04 / 2020$

\section{People with Pre-existing Medical Conditions}

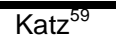

?

]

People with rheumatic diseases enrolled in a

longitudinal registry (National Databank for

Rheumatic Diseases)

Liang $^{60}$

Patients with maintenance hemodialysis under medical quarantine in a single hospital

03-06/2020

$12 / 2019$

China

$02-03 / 2020$

People with systemic sclerosis enrolled in an ongoing longitudinal cohort
Canada, France,

07-12/2019

435

$57(13)$

89 
$05 / 2020$

Adults aged $\geq 60$ with $\geq 2$ chronic medical conditions recruited from 4 primary care clinics

\section{$04 / 2018$}

$03 / 2019$
583

$71(6)$

$03-04 / 2020$

\section{Medical Staff}

Li, Weidong

?

?

Training physicians from 12 Shanghai hospitals

China

$10 / 2019$

385

Median (IQR):

25 (23-28)

$01 / 2020$ minority adults enrolled in a longitudinal cohort

\section{Sexual or Gender Minority Individuals}

\section{Bavinton $^{65}$}

?

]

Gay and bisexual men enrolled in a longitudina cohort
Convenience sample of sexual and gender

United States

?
$01 / 2020$

Flentje ${ }^{66}$

[?

Australia

(2)

\section{NR/2019}

04/2020

$\begin{array}{lll}06 / 2019- & 2,288 & 37(15) \\ 03 / 2020^{9} & \end{array}$

04/2020

\footnotetext{
${ }^{a}$ Based on 671 participants with data during COVID-19. ${ }^{b}$ Analyses compared COVID-19 symptom levels to preceding trends across multiple assessments. ${ }^{\mathrm{C}} \mathrm{Number}$ included in fixed effects regression analysis from where the majority of data were extracted. ${ }^{\mathrm{d}}$ Age groups reported for Daly ${ }^{34}$; for Pierce, ${ }^{30} 16-24=9 \%, 25-34=11 \%, 35-44=16 \%, 45-54=20 \%, 55-69=29 \%, 70+=$ $15 \%$. ${ }^{\text {SS}}$ Same percent for Daly ${ }^{34}$ and Pierce. ${ }^{30}$ f Based on van der Velden. ${ }^{34}$ Included because estimated that over $80 \%$ of pre-COVID-19 data would have been collected by December 31 ,
}

2019. hased on female sex assigned at birth; 12 gender categories listed in study. 
Table 2. Adequacy of methods and reporting of included studies $(\mathrm{N}=36)$

\begin{tabular}{|c|c|c|c|c|c|c|c|c|c|}
\hline Author & $\begin{array}{l}\text { Appropriate } \\
\text { sample } \\
\text { frame }\end{array}$ & $\begin{array}{l}\text { Appropriate } \\
\text { participant } \\
\text { recruitment }\end{array}$ & $\begin{array}{c}\text { Adequate } \\
\text { sample size }\end{array}$ & $\begin{array}{l}\text { Participants } \\
\text { and setting } \\
\text { adequately } \\
\text { described }\end{array}$ & $\begin{array}{c}\text { Adequate } \\
\text { response rate } \\
\text { and data } \\
\text { analysis with } \\
\text { sufficient } \\
\text { coverage }\end{array}$ & $\begin{array}{c}\text { Valid } \\
\text { methods for } \\
\text { identification } \\
\text { of outcome } \\
\text { variable }\end{array}$ & $\begin{array}{l}\text { Standard, } \\
\text { reliable } \\
\text { outcome } \\
\text { measurement }\end{array}$ & $\begin{array}{l}\text { Appropriate } \\
\text { statistical } \\
\text { analysis }\end{array}$ & $\begin{array}{c}\text { Adequate follow- } \\
\text { up response } \\
\text { rate/ appropriate } \\
\text { management of } \\
\text { low response } \\
\text { rate }\end{array}$ \\
\hline \multicolumn{10}{|c|}{ General Population } \\
\hline Castellini $^{33}$ & Unclear & No & Unclear & Yes & Unclear & Yes & Yes & Yes & Yes \\
\hline Daly ${ }^{34}$ & Yes & Yes & Yes & Yes & Unclear & Yes & Yes & Yes & Yes \\
\hline Pierce $^{30}$ & Yes & Yes & Yes & Yes & Unclear & Yes & Yes & Yes & Yes \\
\hline $\mathrm{Katz}^{35}$ & No & No & Yes & Yes & Unclear & Yes & Yes & Yes & Unclear \\
\hline van der Velden ${ }^{36}$ & Yes & Yes & Yes & Yes & Yes & Yes & Yes & Yes & Yes \\
\hline van der Velden ${ }^{37}$ & Yes & Yes & Yes & Yes & Yes & Yes & Yes & Yes & Yes \\
\hline \multicolumn{10}{|l|}{ Older Adults } \\
\hline Creese $^{38}$ & Yes & No & Yes & Yes & No & Yes & Yes & Yes & Yes \\
\hline $\mathrm{Kivi}^{39}$ & Yes & Unclear & Yes & Yes & No & Yes & Yes & Yes & No \\
\hline Okely $^{40}$ & No & No & Unclear & Yes & No & Yes & Yes & Yes & No \\
\hline van Tilburg $^{41}$ & Yes & Yes & Yes & Yes & Yes & Yes & Yes & Yes & Yes \\
\hline Wang $^{42}$ & Yes & Yes & Yes & Yes & Unclear & Yes & Yes & Yes & No \\
\hline \multicolumn{10}{|l|}{ Young Adults } \\
\hline Marmet $^{43}$ & Yes & Yes & Yes & Yes & Unclear & Yes & Yes & Yes & No \\
\hline Rimfeld $^{44}$ & Yes & Unclear & Yes & Yes & Unclear & Yes & Yes & Yes & Unclear \\
\hline
\end{tabular}




\begin{tabular}{|c|c|c|c|c|c|c|c|c|c|}
\hline \multicolumn{10}{|c|}{ Children and Adolescents } \\
\hline Achterberg $^{45 a}$ & No & No & Unclear & Yes & Unclear & Yes & No & Yes & Yes \\
\hline Ezpeleta $^{46}$ & No & No & Unclear & Yes & No & Yes & No & Yes & Unclear \\
\hline Magson $^{47}$ & No & Unclear & Yes & Yes & Unclear & Yes & Yes & Yes & No \\
\hline Zhang $^{48}$ & No & No & Yes & Yes & Yes & Yes & Yes & Yes & Yes \\
\hline \multicolumn{10}{|l|}{ Parents } \\
\hline Achterberg $^{45 a}$ & No & Unclear & Unclear & Yes & Unclear & Yes & Yes & Yes & No \\
\hline \multicolumn{10}{|c|}{ University Students } \\
\hline Dong $^{49}$ & No & No & Yes & Yes & Yes & Yes & Yes & Yes & Yes \\
\hline Elmer ${ }^{50}$ & No & Yes & Yes & Yes & Unclear & Yes & Yes & Yes & Unclear \\
\hline Huckins $^{52}$ & No & No & Unclear & Yes & Unclear & Yes & Yes & No & Unclear \\
\hline Li, Hongyan ${ }^{53}$ & No & Unclear & Yes & Yes & Unclear & Yes & Yes & Yes & Yes \\
\hline Li, Renli ${ }^{54}$ & No & Yes & Yes & No & Unclear & Yes & Yes & Yes & Yes \\
\hline Li, Wendy Wen ${ }^{55}$ & No & No & Unclear & Yes & No & Yes & Yes & Yes & Yes \\
\hline Saraswathi ${ }^{56}$ & No & Yes & Unclear & Yes & Yes & Yes & Yes & Yes & Yes \\
\hline Savage $^{57}$ & No & Yes & Yes & Yes & No & Yes & Yes & Yes & No \\
\hline Zimmerman $^{58}$ & No & No & Yes & Yes & Unclear & Yes & Yes & Yes & Yes \\
\hline \multicolumn{10}{|c|}{ People with Pre-existing Medical Conditions } \\
\hline $\mathrm{Katz}^{59}$ & Unclear & Unclear & Yes & Yes & Unclear & Yes & Yes & Yes & No \\
\hline Ubara $^{62}$ & No & Unclear & Unclear & No & Unclear & Yes & Yes & No & Unclear \\
\hline
\end{tabular}




\begin{tabular}{|c|c|c|c|c|c|c|c|c|c|}
\hline Wong $^{63}$ & No & Unclear & Yes & Yes & Unclear & Yes & Yes & Yes & Yes \\
\hline \multicolumn{10}{|l|}{ Medical Staff } \\
\hline Li, Weidong $^{64}$ & No & Unclear & Yes & Yes & No & Yes & Yes & Yes & No \\
\hline \multicolumn{10}{|c|}{ Sexual or Gender Minority Individuals } \\
\hline Bavinton $^{65}$ & Yes & Unclear & Yes & No & Unclear & Yes & Yes & Yes & Unclear \\
\hline Flentje $^{66}$ & Yes & No & Yes & Yes & Unclear & Yes & Yes & Yes & Unclear \\
\hline
\end{tabular}

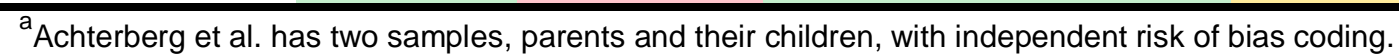


「able 3. General Mental Health Outcomes in Included Studies and Subgroups of Included Studies ${ }^{a}$

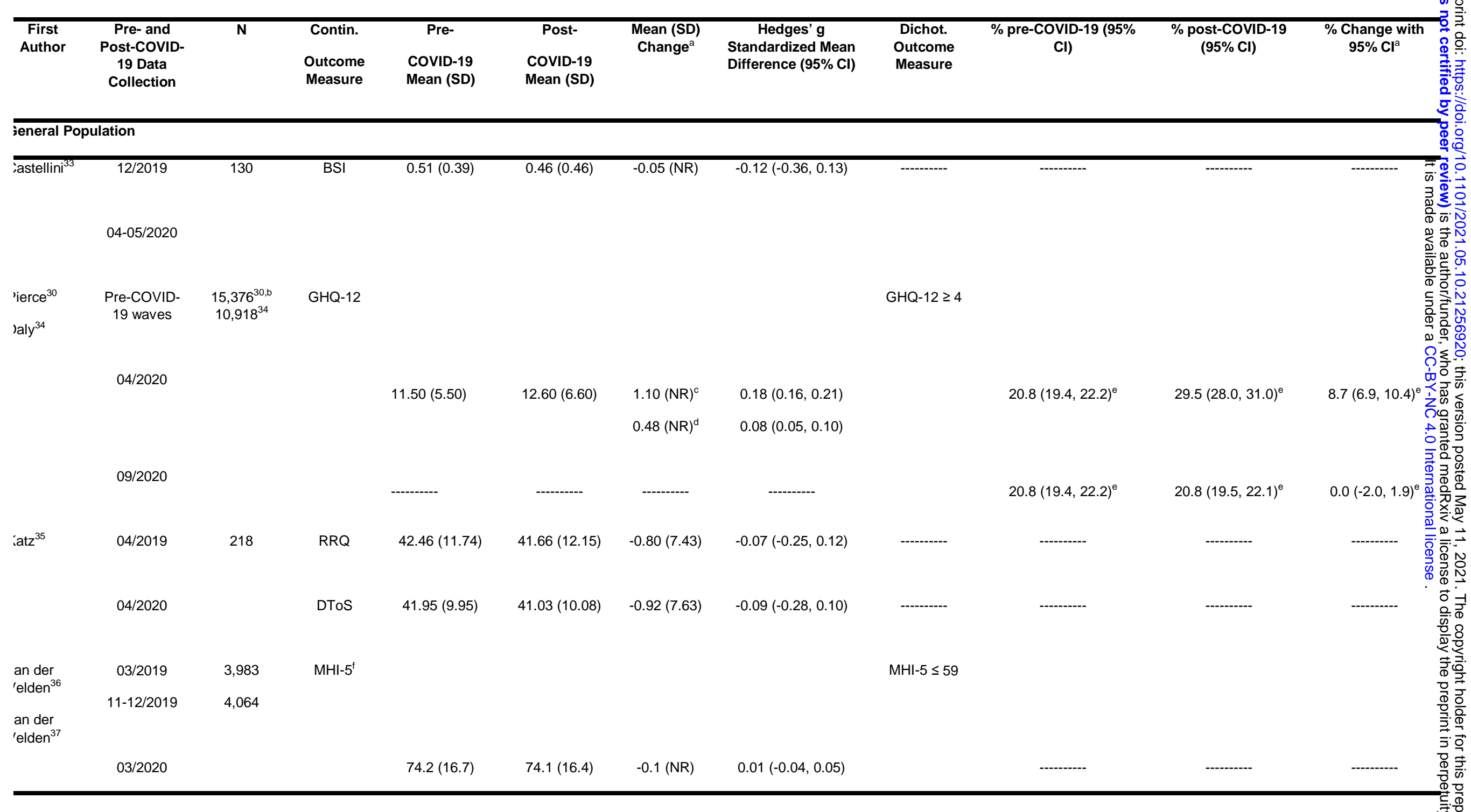




\begin{tabular}{lccc}
\hline 'ierce & Pre-COVID- & $2,633(\geq 70$ & GHQ-12 \\
saly $^{34}$ & 19 waves & years $)^{30, b}$ & \\
& & $3,447(\geq 65$ & \\
& & years $)^{34}$ &
\end{tabular}

04/2020

$\begin{array}{llll}10.10(4.57) & 10.90(5.35) & 0.80(\mathrm{NR})^{\mathrm{c}} & 0.16(0.11,0.21) \\ & 0.05(\mathrm{NR})^{\mathrm{d}} & 0.01(-0.04,0.06)\end{array}$

\section{GHQ-12 $\geq 4$}

$3,447(\geq 65$
years $)^{34}$

$09 / 2020$

ivi ${ }^{39} \quad$ Pre-CoviD-

19 waves

1,071

$\operatorname{SWLS}^{\dagger}$
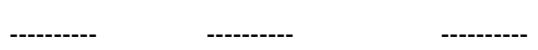

03-04/2020

NR/2017-

137

WEMWBS $^{\dagger}$

$37.45(8.37)$

$36.45(8.23)$

-1.00 (NR)

$0.12(-0.12,0.36)$

05-06/2020

an der

'elden ${ }^{36}$

an der

'elden ${ }^{37}$

an

ïlburg ${ }^{41}$

\section{$5.12(1.30)$ \\ $5.16(1.26)$ \\ 0.04 (NR) \\ $-0.03(-0.12,0.05)$}

\begin{tabular}{|c|c|}
\hline 03/2019 & $949-1,038$ \\
\hline $11-12 / 2019$ & $968-1,052$ \\
\hline & 1,679 \\
\hline $03 / 2020^{36}$ & \\
\hline $05 / 2020^{41}$ & \\
\hline
\end{tabular}

$\mathrm{MHI}-5 \leq 59$

$4.93(0.75)$
$5.02(0.73)$
$0.09(0.58)$
$-0.12(-0.19,-0.05)$ $12.7(10.3,15.1)^{\mathrm{e}}$

$--\cdot$

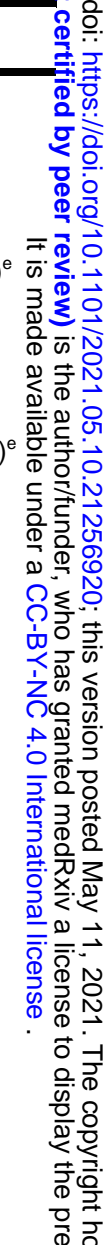

\section{$10.9(9.0,13.0) \quad 10.6(8.9,12.6) \quad-0.2(-2.3,1.9)$}




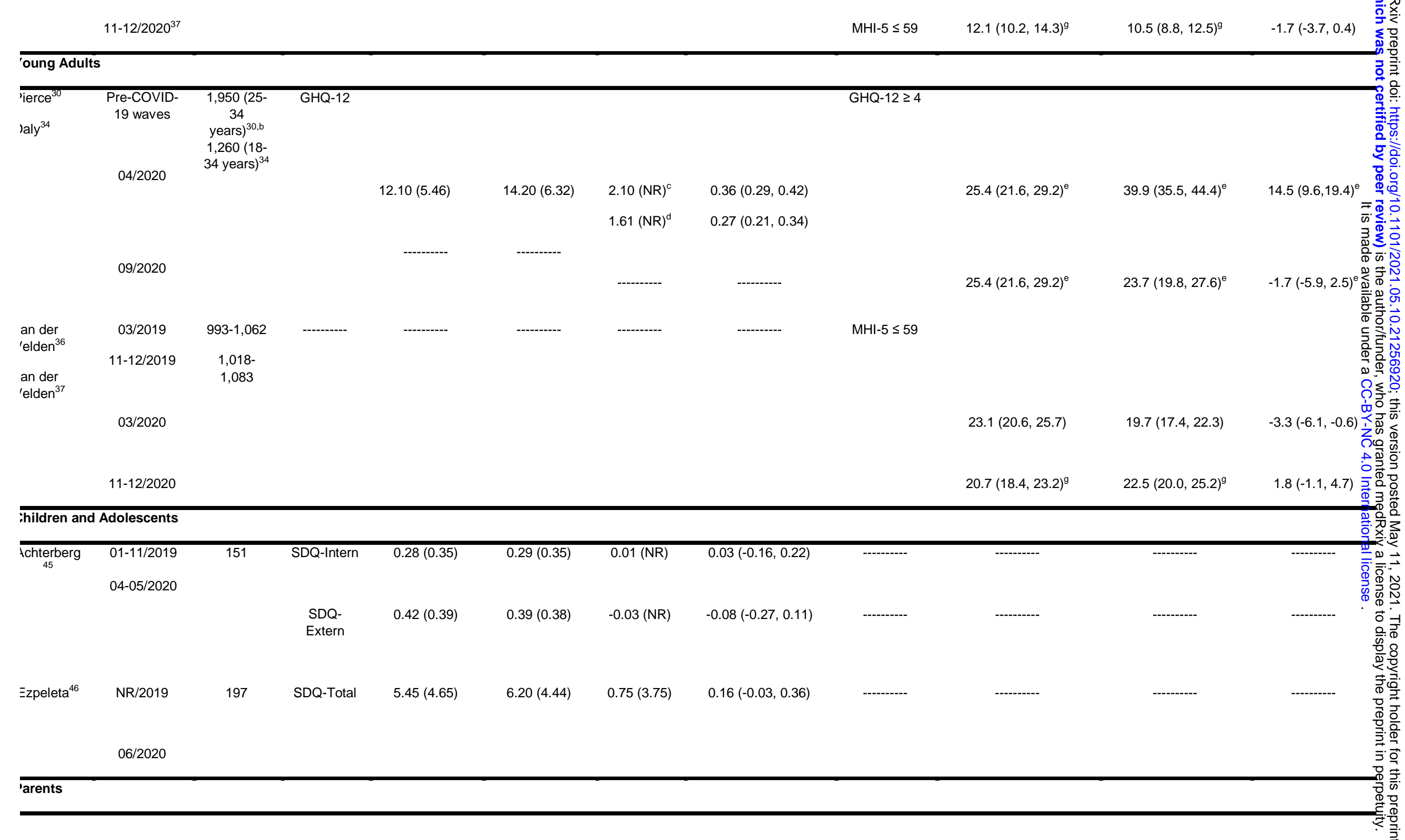




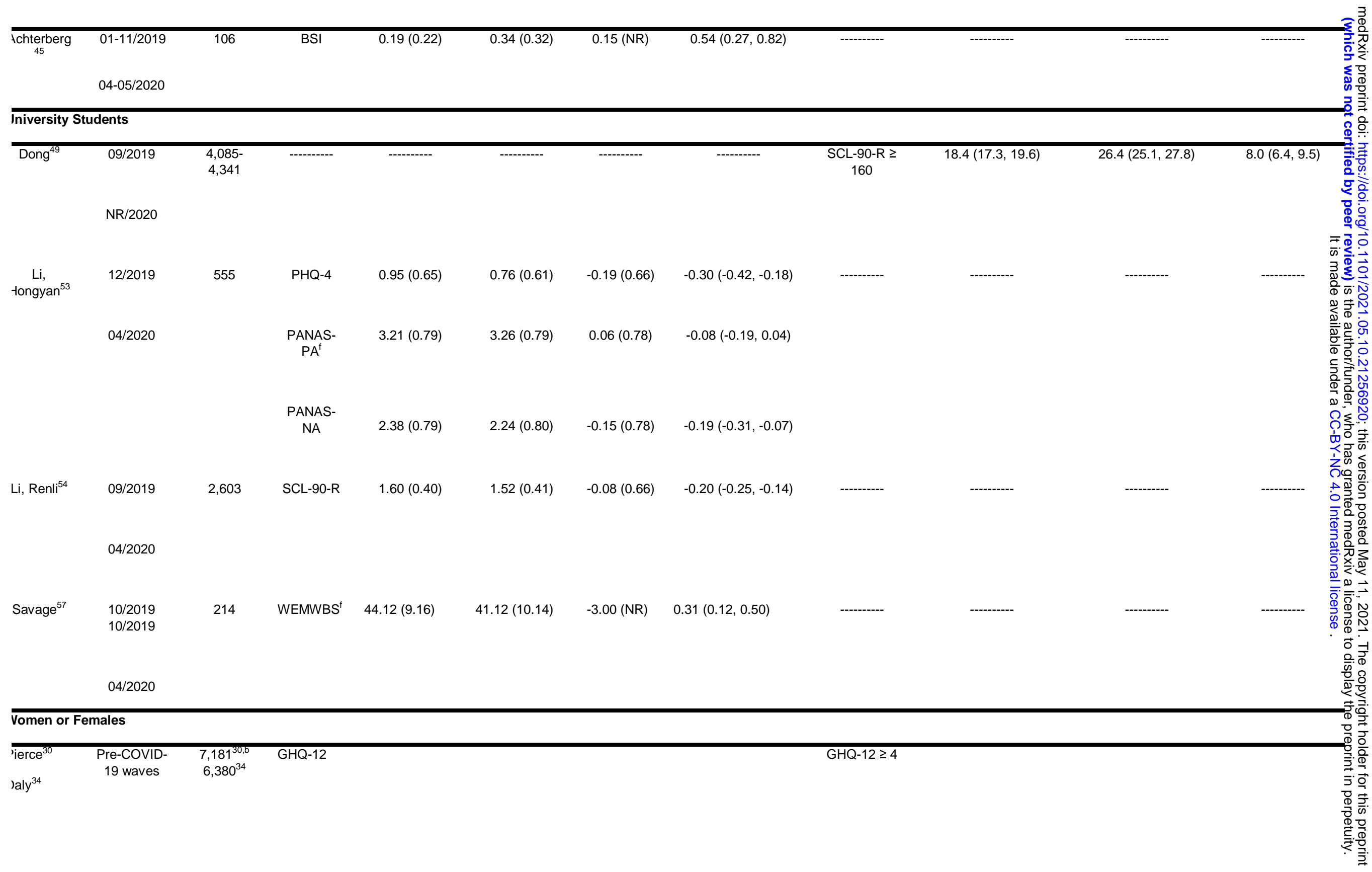




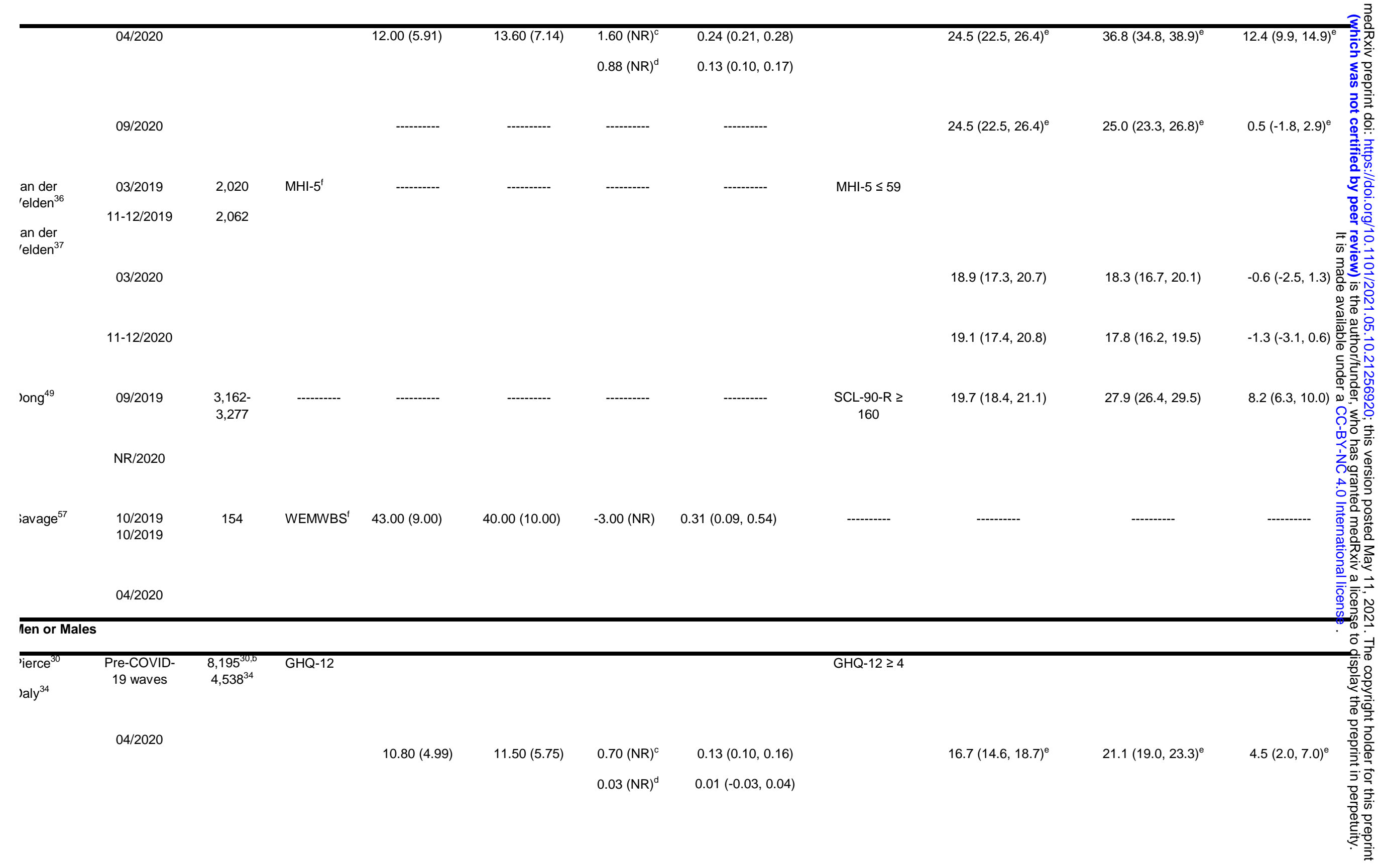


---------

---------

---------

MHI- $5^{\dagger}$

1,962

an der

'elden ${ }^{36}$

an der

'elden ${ }^{37}$

$11-12 / 2019$

2,002

$03 / 2020$

$11-12 / 2020$

long ${ }^{4}$

09/2019

923-1,064

NR/2020
10/2019

60

WEMWBS $^{\dagger} \quad 47.00(9.00)$

$44.00(10.00)$

$-3.00(N R)$

$0.31(-0.05,0.67)$

$04 / 2020$

(20)

MHI- $5 \leq 59$

$14.6(13.1,16.3) \quad 15.6(14.1,17.3) \quad 1.0(-0.8,2.7)$

$14.7(13.2,16.3)$

$15.9(14.4,17.6)$

SCL-90-R $\geq$

$14.3(12.3,16.5)$

$21.2(18.7,24.0)$ 
「able 4. Anxiety Symptom Outcomes in Included Studies and Subgroups of Included Studies ${ }^{a}$

\begin{tabular}{|c|c|c|c|c|c|c|c|c|c|c|c|}
\hline -irst Author & $\begin{array}{c}\text { Pre- and } \\
\text { Post- } \\
\text { cOvID-19 } \\
\text { Data } \\
\text { Collection }\end{array}$ & $\overline{\mathbf{N}}$ & $\begin{array}{l}\text { Contin. } \\
\text { Outcome } \\
\text { Measure }\end{array}$ & $\begin{array}{c}\text { Pre- } \\
\text { CovID-19 } \\
\text { Mean (SD) }\end{array}$ & $\begin{array}{c}\text { Post- } \\
\text { CoVID-19 } \\
\text { Mean (SD) }\end{array}$ & $\begin{array}{c}\text { Mean (SD) } \\
\text { Change }^{a}\end{array}$ & $\begin{array}{c}\text { Hedges' g } \\
\text { Standardized Mean } \\
\text { Difference }(95 \% \mathrm{Cl})\end{array}$ & $\begin{array}{l}\text { Dichot. } \\
\text { Outcome } \\
\text { Measure }\end{array}$ & $\begin{array}{l}\text { \% pre-COVID-19 (95\% } \\
\mathrm{Cl})\end{array}$ & $\begin{array}{l}\text { \% post-COVID-19 } \\
(95 \% \mathrm{Cl})\end{array}$ & $\begin{array}{l}\text { \% Change with } \\
\qquad 5 \% \mathrm{Cl}^{\mathrm{a}}\end{array}$ \\
\hline$\overline{\operatorname{senz} z^{32}}$ & $\begin{array}{l}10-12 / 2019 \\
04-05 / 2020\end{array}$ & $\overline{102}$ & $\begin{array}{l}\text { BSI-18- } \\
\text { Anxiety }\end{array}$ & $10.20(3.44)$ & $9.37(3.05)$ & $-0.84(3.12)$ & $-0.26(-0.53,0.02)$ & 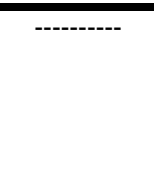 & (---- & (--- & \\
\hline $\mathrm{atz}^{35}$ & $\begin{array}{l}04 / 2019 \\
04 / 2020\end{array}$ & 218 & $\begin{array}{l}\text { DASS-21 } \\
\text { Anxiety }\end{array}$ & $3.25(3.91)$ & $2.83(3.61)$ & $-0.42(3.13)$ & $-0.11(-0.30,0.08)$ & --------- & --------- & --------- & --------- \\
\hline \multicolumn{12}{|l|}{ Ider Adults } \\
\hline ;eese $^{38}$ & $\begin{array}{c}10 / 2019 \\
05-06 / 2020\end{array}$ & 3,281 & GAD-7 & $1.55(2.64)$ & $1.94(2.84)$ & 0.39 (NR) & $0.14(0.09,0.19)$ & & & & \\
\hline Vang $^{42}$ & $\begin{array}{l}10 / 2019 \\
05 / 2020\end{array}$ & 6,467 & ------- & -------- & -------- & -------- & -------- & GAD- $2 \geq 2$ & $5.0(4.4,5.5)$ & $10.1(9.4,10.8)$ & $5.1(4.4,5.9)$ \\
\hline \multicolumn{12}{|l|}{ 'oung Adults } \\
\hline Simfeld $^{44}$ & $\begin{array}{c}\mathrm{NR} / 2018 \\
\text { 04-05/2020 }\end{array}$ & $\begin{array}{l}3,563- \\
3,694\end{array}$ & GAD-7 & $7.48(7.35)$ & $8.69(7.54)$ & $1.21(6.83)$ & $0.16(0.12,0.21)$ & -------- & ------- & --------- & \\
\hline
\end{tabular}




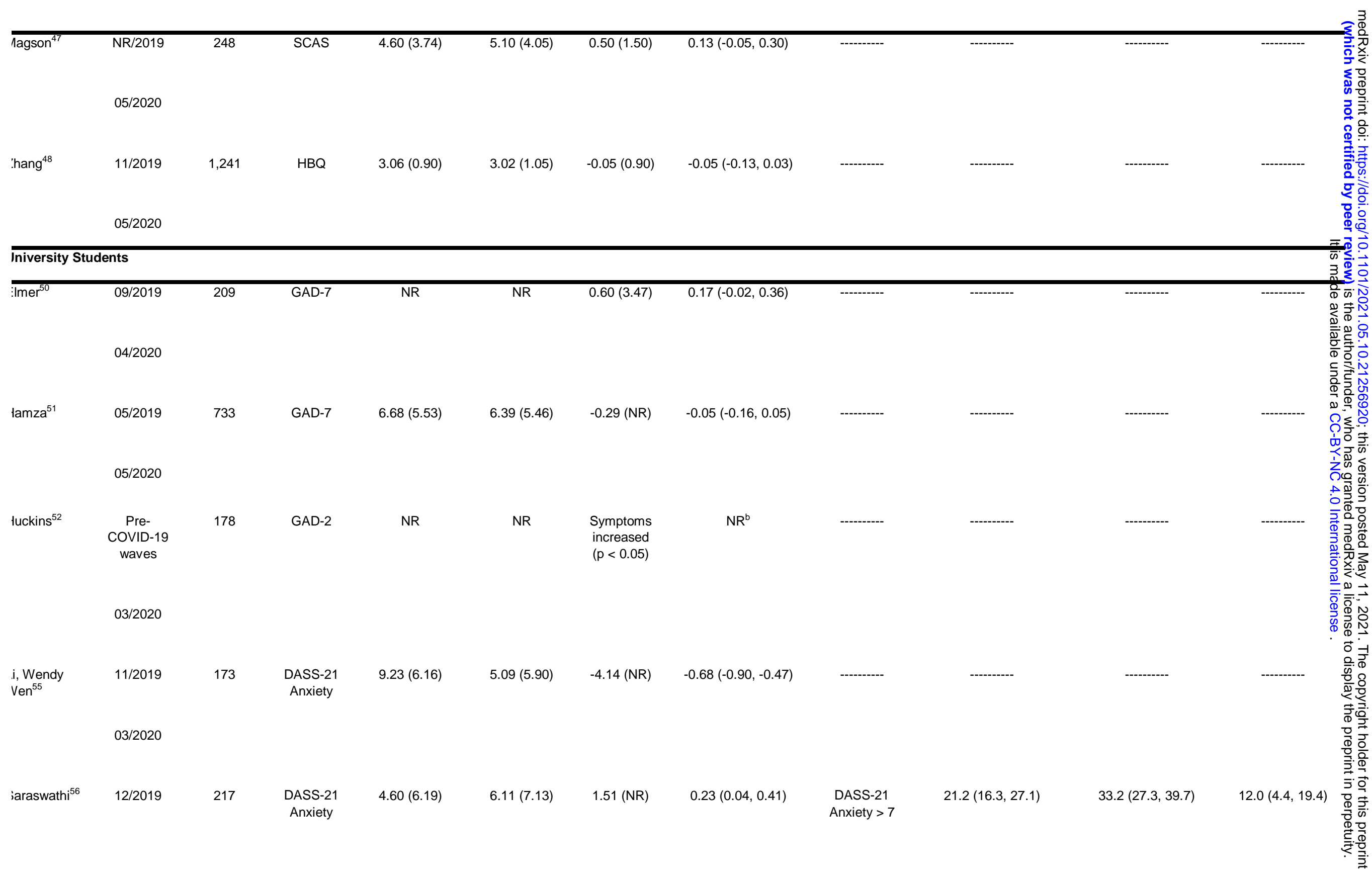


$06 / 2020$

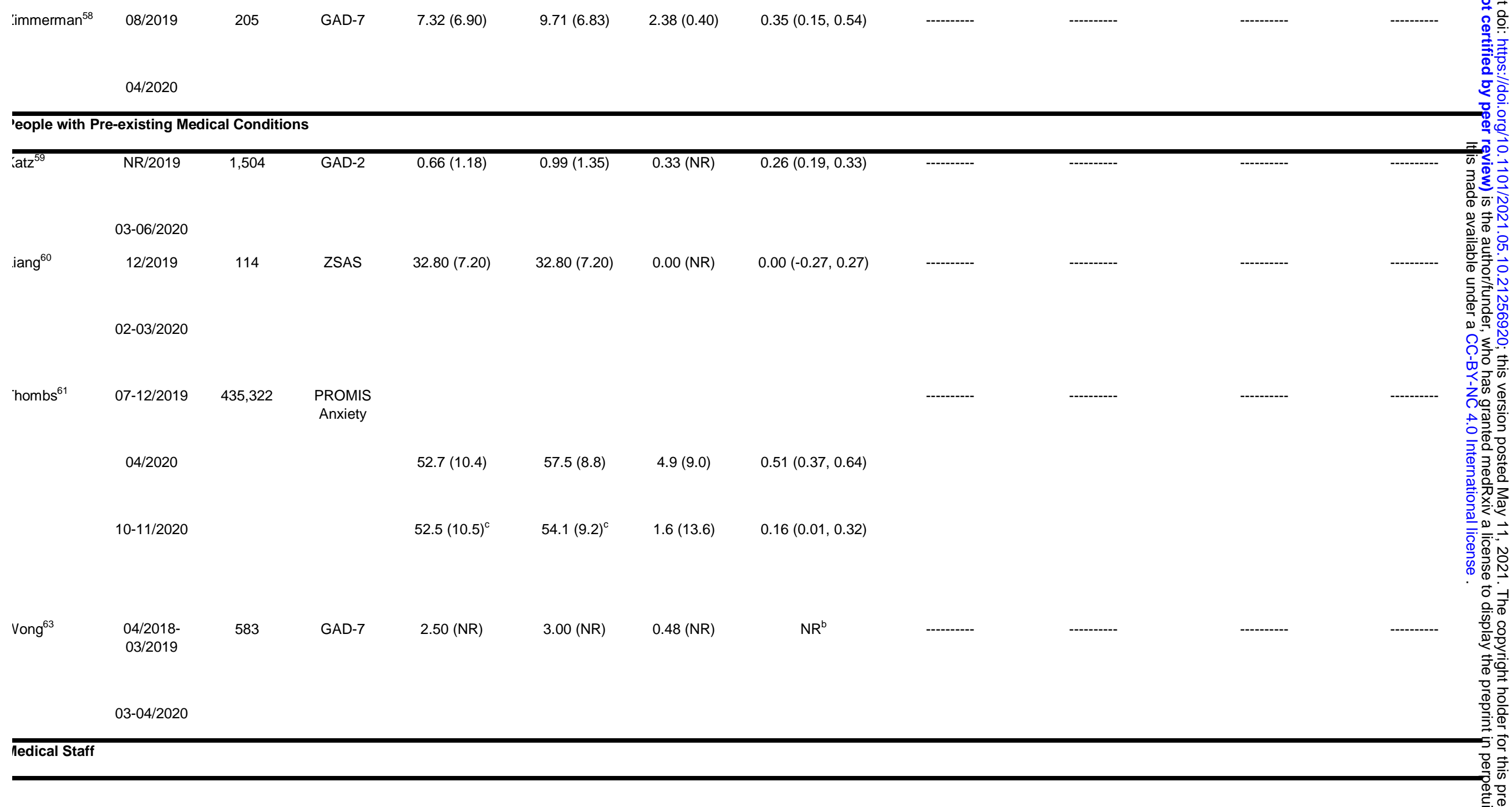




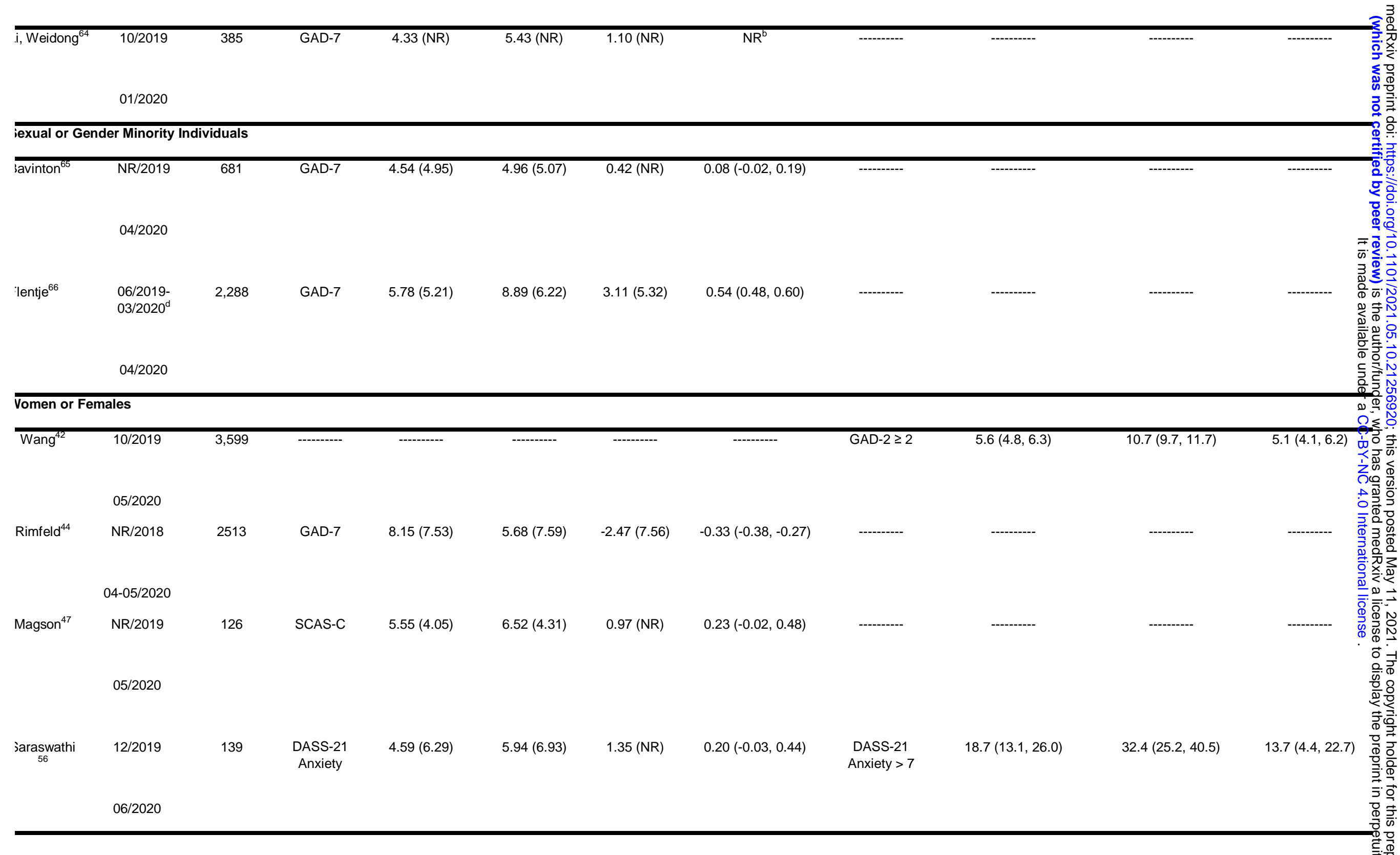




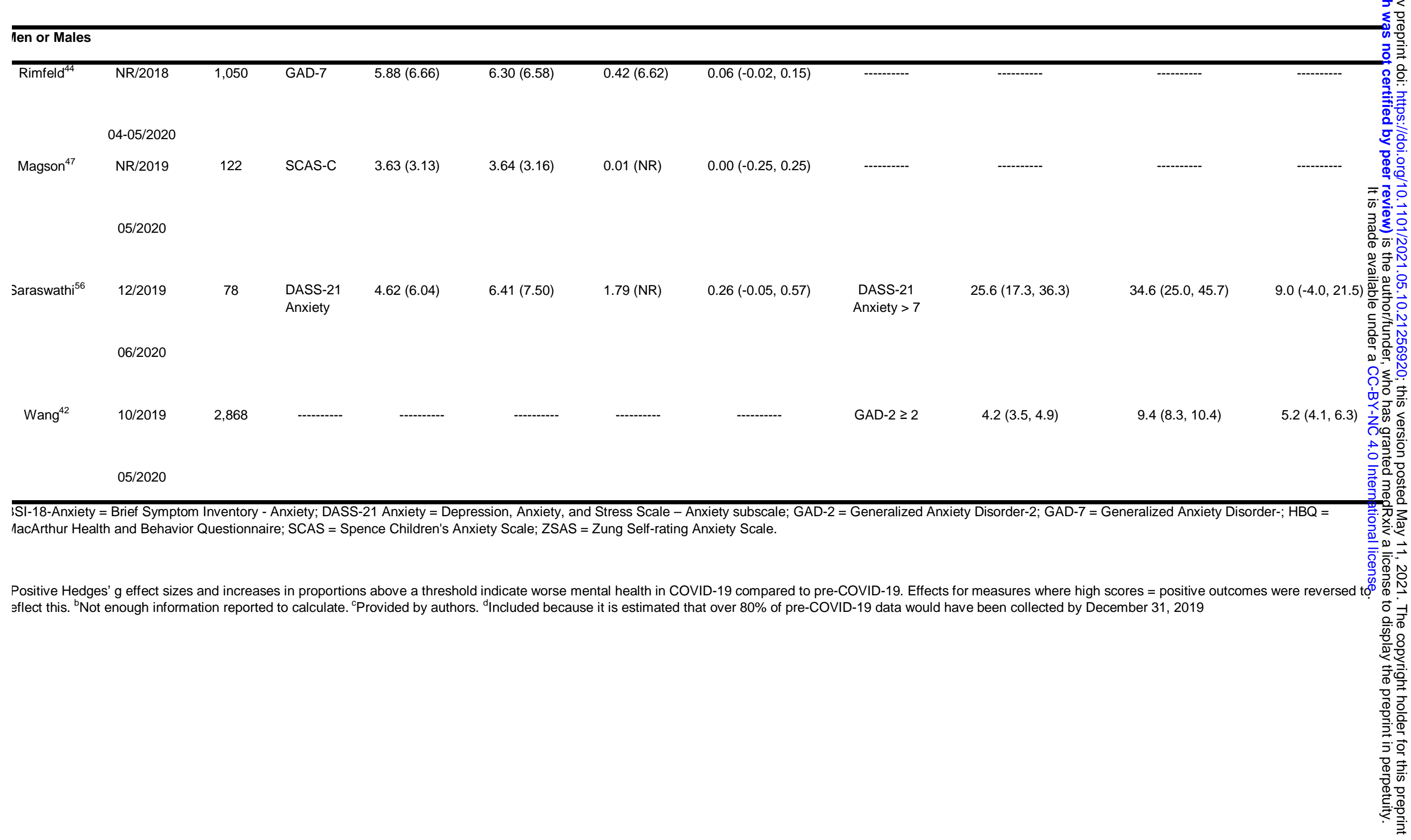


「able 5. Depression Symptom Outcomes in Included Studies and Subgroups of Included Studies ${ }^{a}$

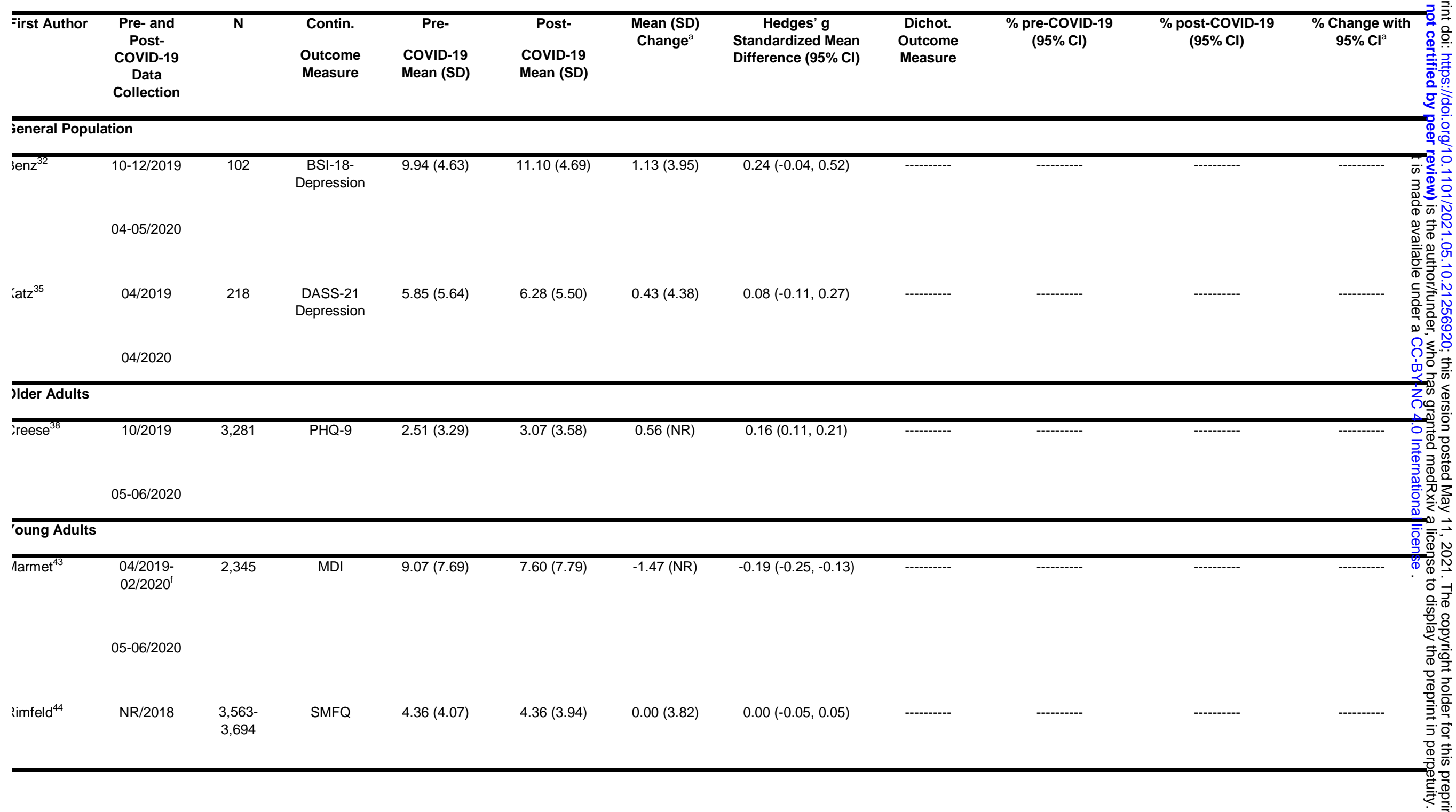


04-05/2020

\section{'hildren and Adolescents}

$\operatorname{lagson}^{47} \quad \mathrm{NR} / 2019$

248

SMFQ

$3.81(4.31)$

$6.12(6.04)$

$2.31(5.81)$

$0.44(0.26,0.62)$

$05 / 2020$

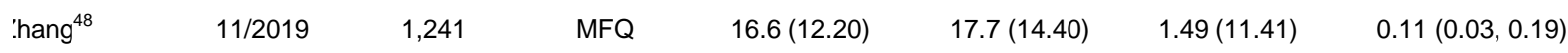

05/2020

Iniversity Students

$\operatorname{Imer}$

tamza

733

CES-D $\quad 17.62(13.46)$

$18.44(13.24)$

$0.82(\mathrm{NR})$

$0.06(-0.04,0.16)$

$05 / 2020$

uckins $^{52}$

$$
\text { Pre- }
$$

COVID-19

178

NR

Symptoms

increased ( $p$

$N R^{c}$

$<0.05)$

03/2020

$11 / 2019$

173

DASS-21

$6.25(6.15)$

$4.99(6.15)$

-1.26 (NR)

$-0.20(-0.41,0.01)$

---------

(2)

$03 / 2020$

$0.53(0.33,0.72)$

---------

----------
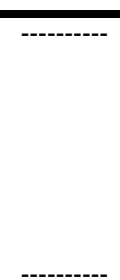


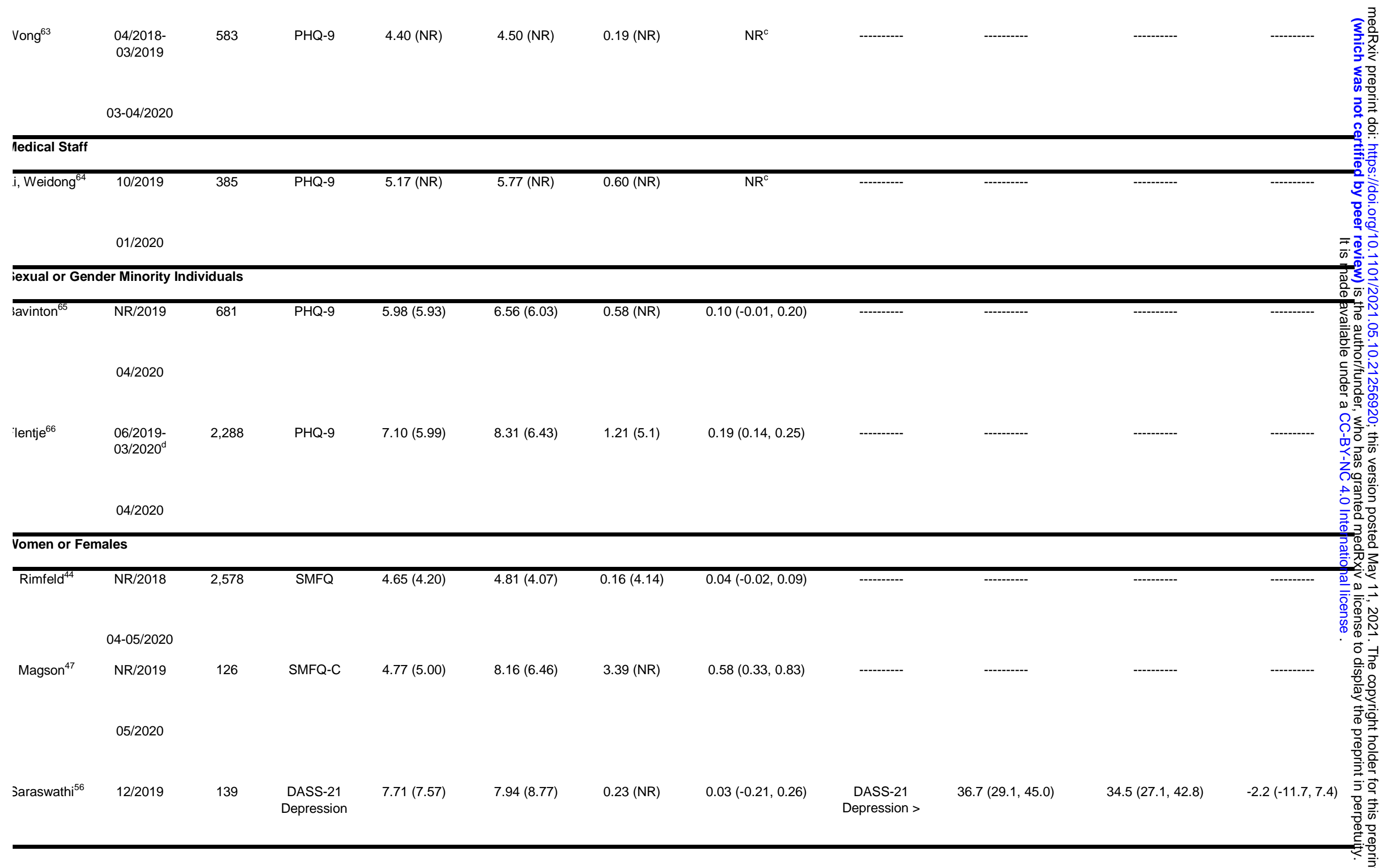




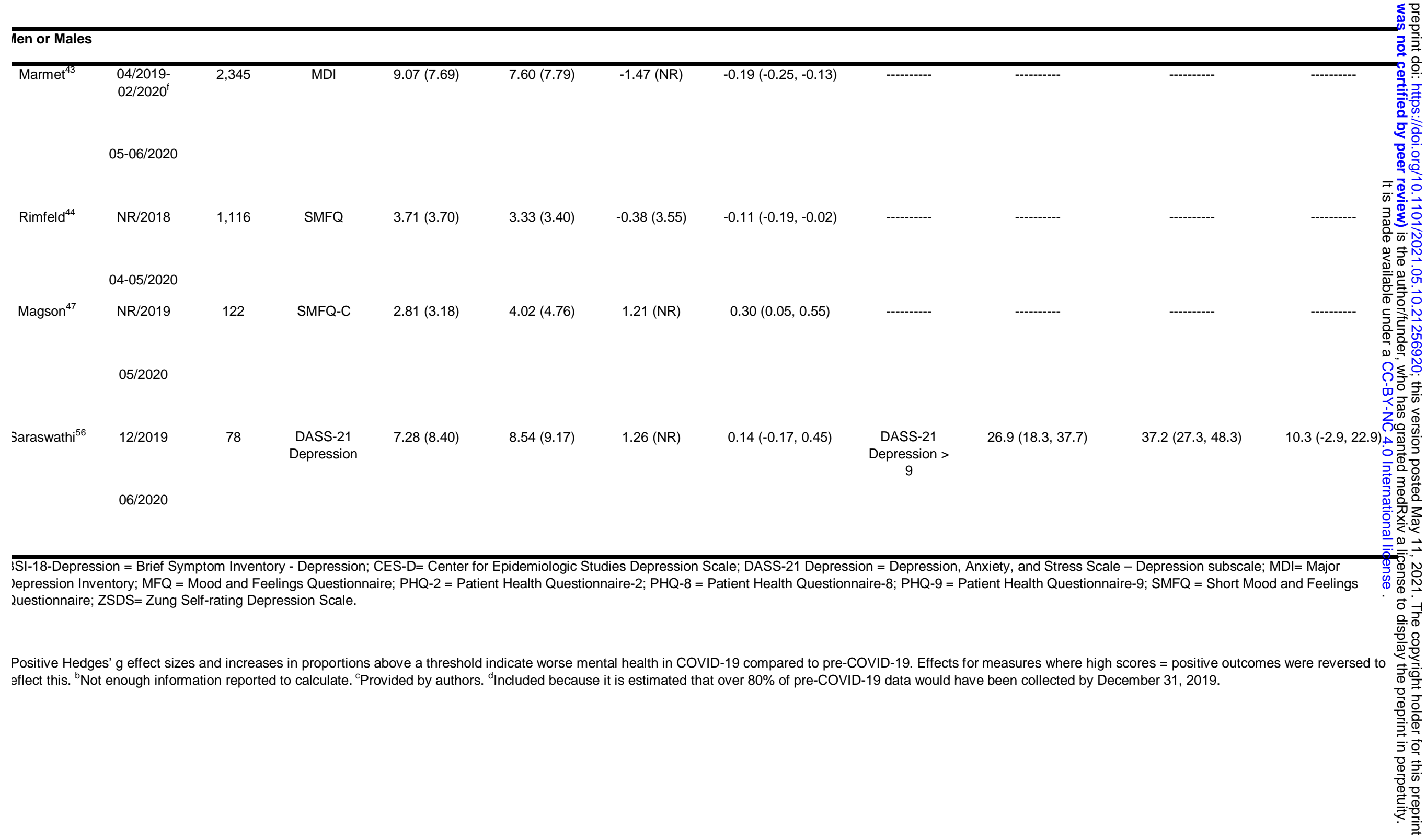




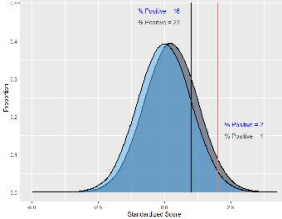


Figure 1. PRISMA 2009 Flow Diagram: Searches through March 22, 2021

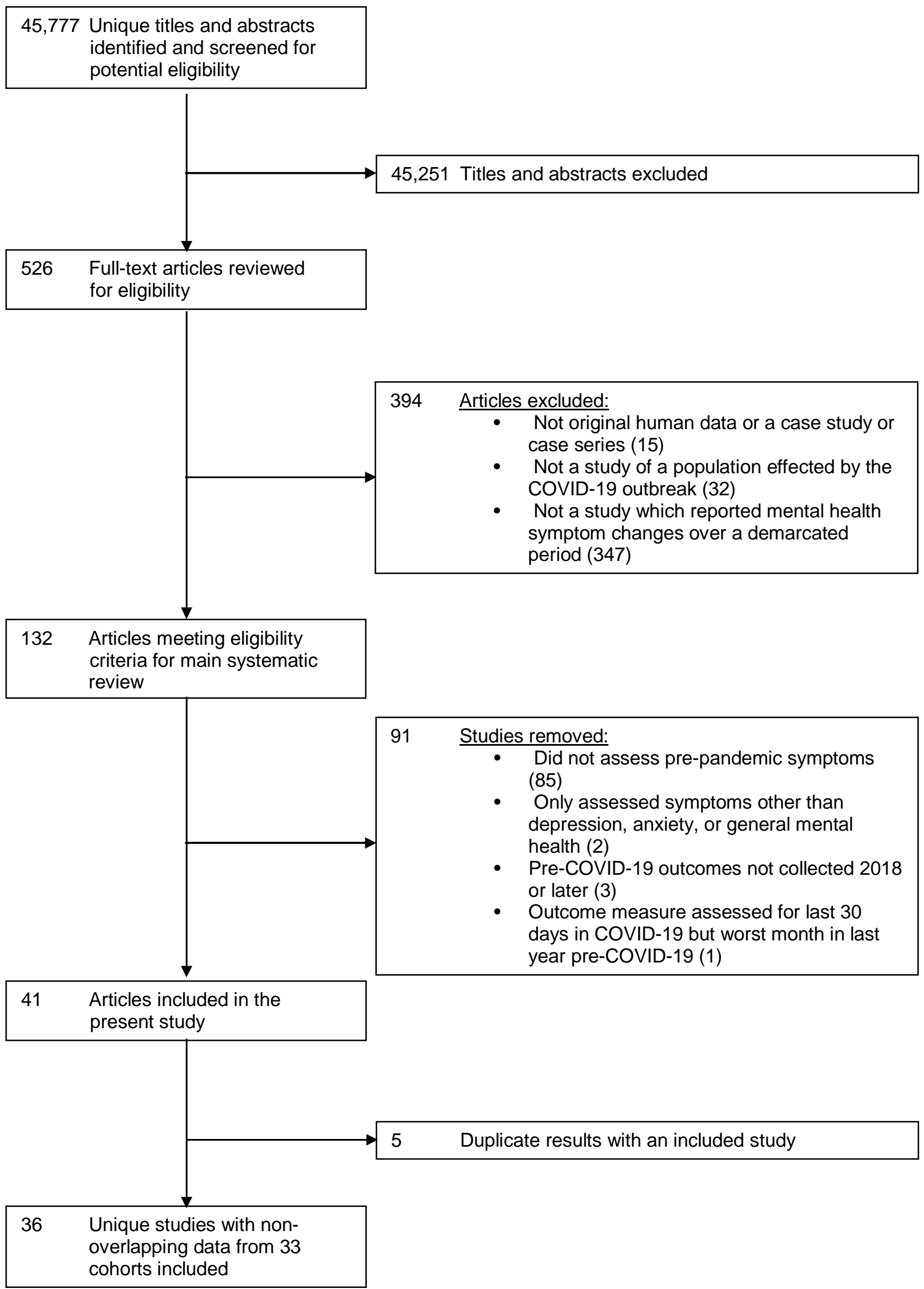


Castellini (12/2019; 04-05/2020)

Daly/Pierce (Pre-COVID-19 waves; 04/2020) Katz (04/2019;04/2020)

van der Velden (03/2019,11-12/2019; 03/2020,11-12/2020)

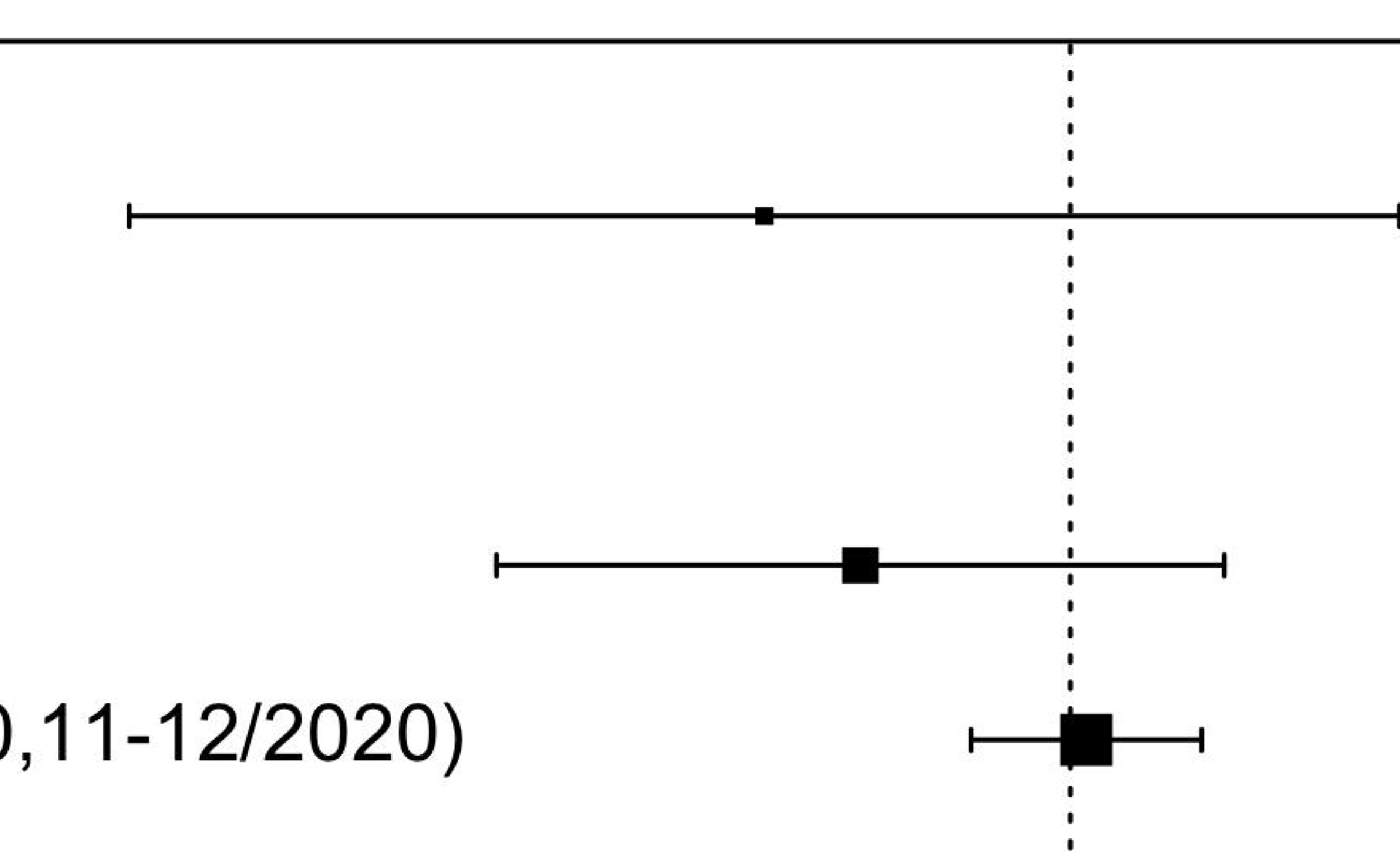

130

$-0.12[-0.36,0.13]$

15376

218

$0.18[0.16,0.21]$

3983

$-0.08[-0.22,0.06]$

$0.01[-0.04,0.05]$

Pooled estimate (random-effects meta-analysis)

$\mathrm{I}^{2}=94.6 \%$

\begin{tabular}{cc|ccc|}
\hline \multicolumn{1}{l}{} & $\vdots$ & & & \\
-0.4 & -0.2 & 0 & 0.2 & 0.4 \\
& & SMD & &
\end{tabular}


Castellini (12/2019; 04-05/2020)

Daly/Pierce (Pre-COVID-19 waves; 04/2020)

Katz (04/2019; 04/2020)

van der Velden (03/2019,11-12/2019; 03/2020,11-12/2020)
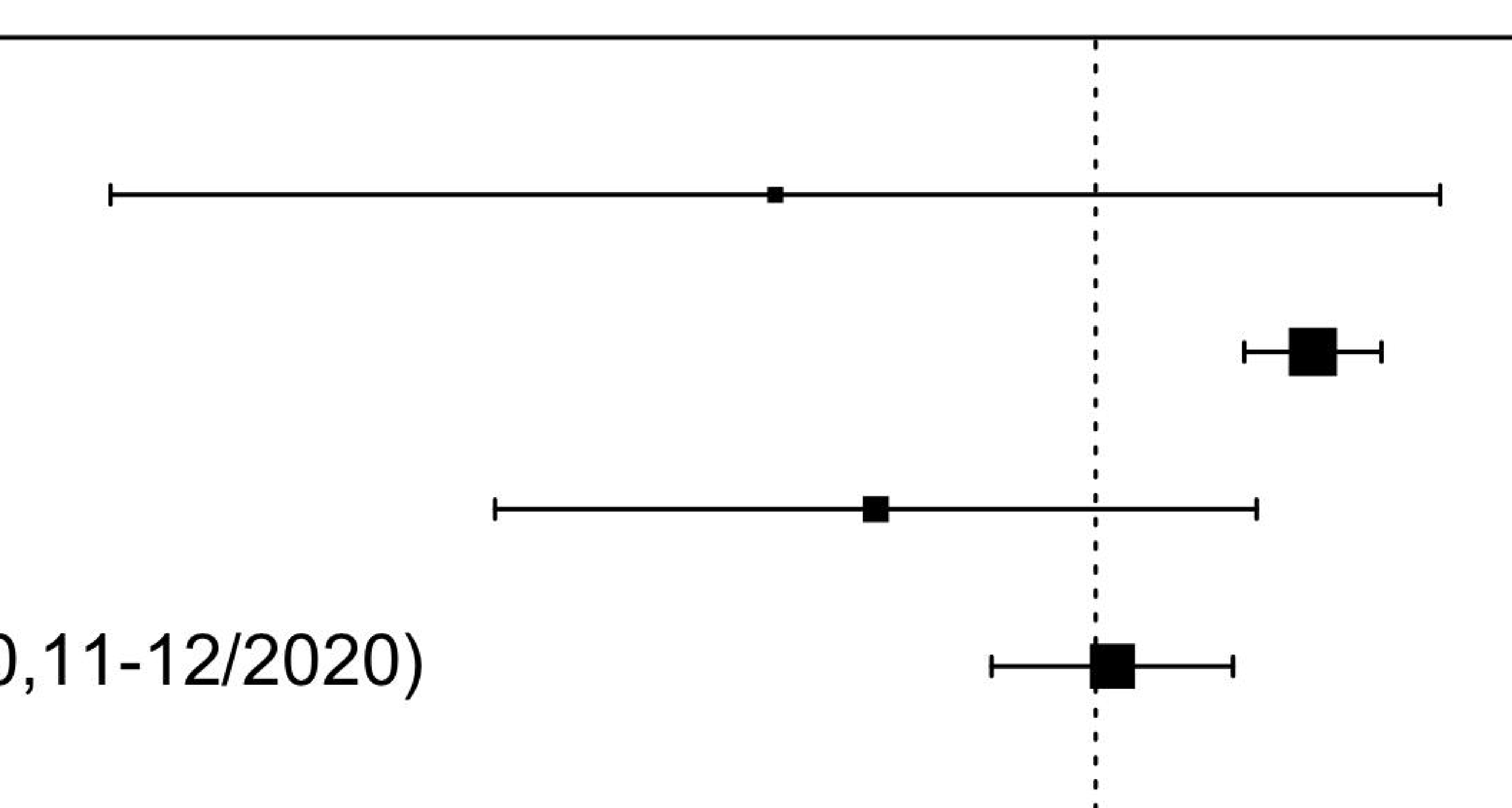

Pooled estimate (random-effects meta-analysis) $\mathrm{I}^{2}=81.8 \%$

130

$-0.12[-0.36,0.13]$

10918

218

3983

15249

$0.01[-0.07,0.09]$ 
Daly/Pierce (Pre-COVID-19 waves; 04/2020) Kivi (Pre-COVID-19 waves; 03-04/2020)

Okely (NR/2017-NR/2019; 05-06/2020)

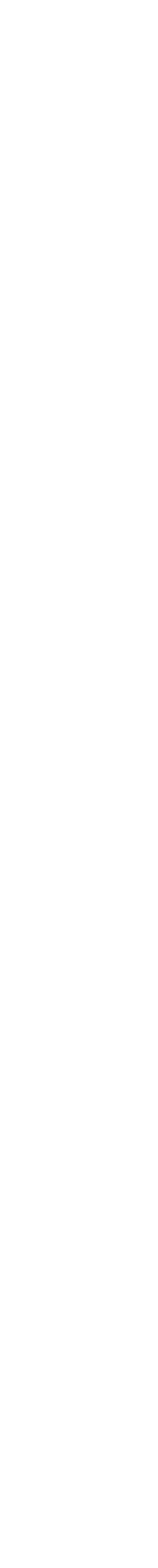

van Tilburg (10-11/2019; 05/2020)

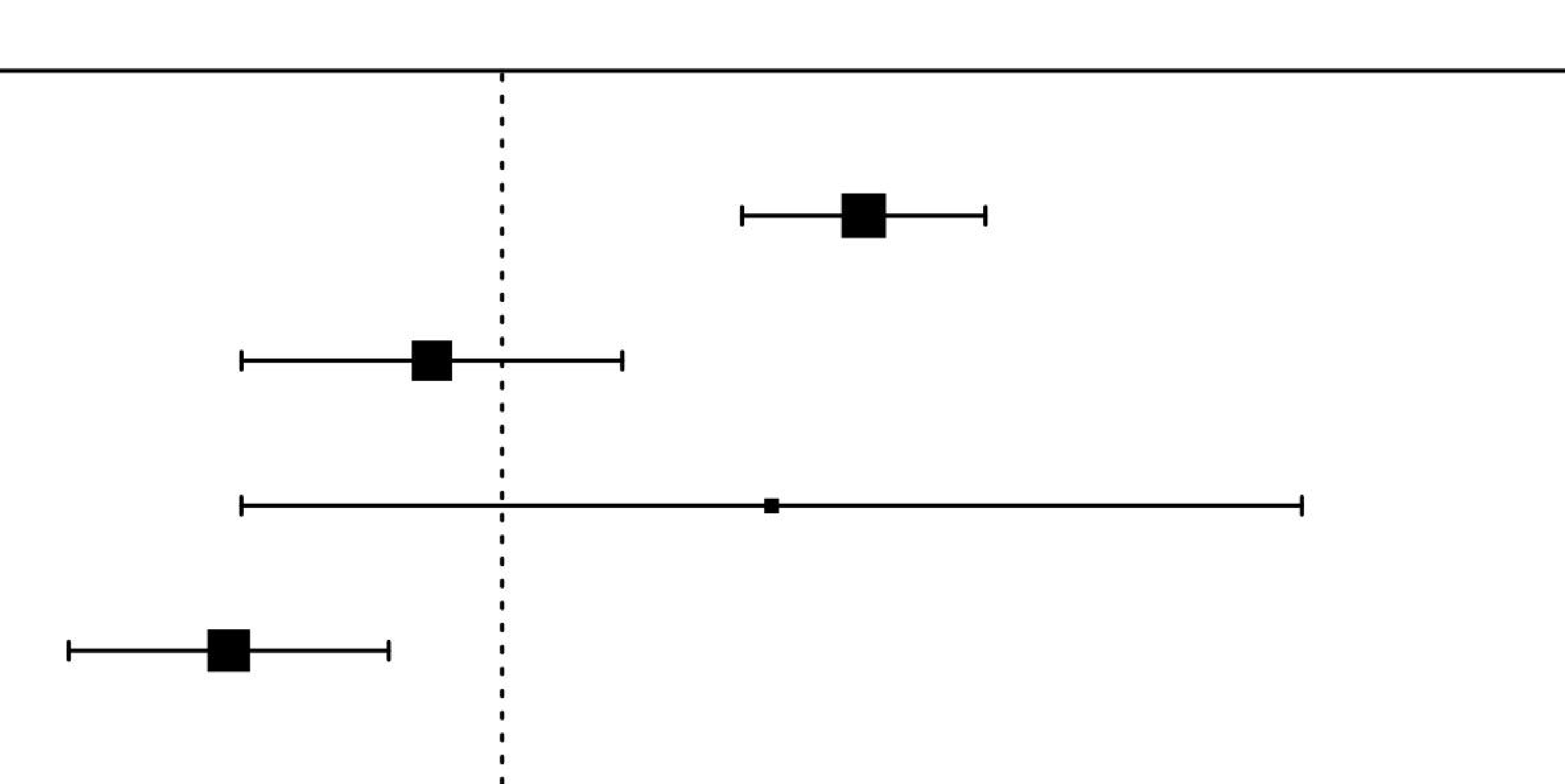

Pooled estimate (random-effects meta-analysis) $I^{2}=90.4 \%$
2633

1071

137

1679

5520

\begin{tabular}{cc|c|ccc|c|}
\hline & $\mid$ & & $\mid$ & & & \\
-0.2 & -0.1 & 0 & 0.1 & 0.2 & 0.3 & 0.4 \\
& & & SMD & & &
\end{tabular}

$0.16[0.11,0.21]$

$-0.03[-0.12,0.05]$

$0.12[-0.12,0.36]$

$-0.12[-0.19,-0.05]$

$0.02[-0.11,0.16]$ 
Daly/Pierce (Pre-COVID-19 waves; 04/2020)

Kivi (Pre-COVID-19 waves; 03-04/2020)

Okely (NR/2017-NR/2019; 05-06/2020)

van Tilburg (10-11/2019; 05/2020)

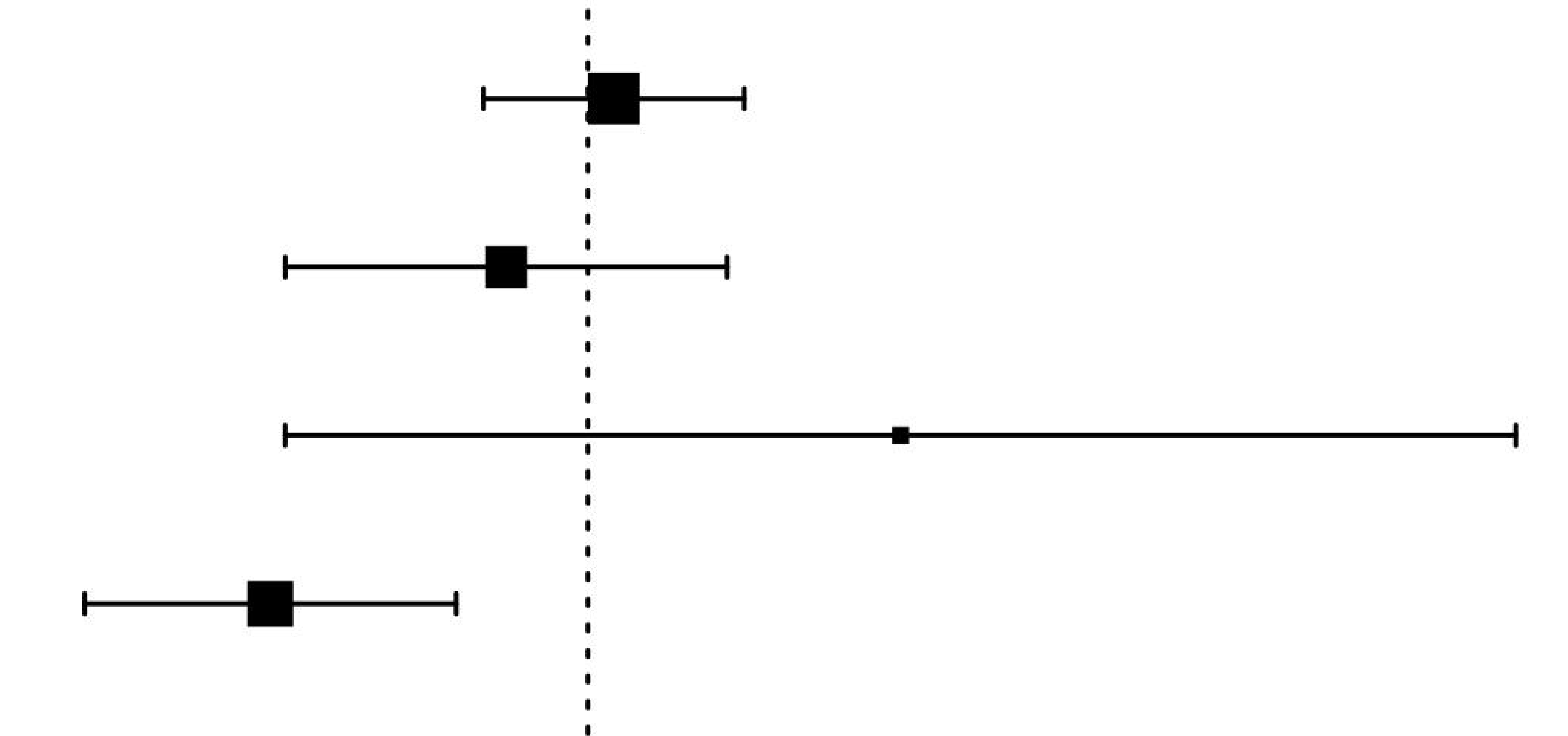

3447

1071

137

1679

6334

Pooled estimate (random-effects meta-analysis)

$1^{2}=69.6 \%$

\begin{tabular}{cc|c|c|cc|c|}
\hline & 1 & & & & & \\
-0.2 & -0.1 & 0 & 0.1 & 0.2 & 0.3 & 0.4 \\
& & & SMD & & &
\end{tabular}

\section{$0.01[-0.04,0.06]$}

$-0.03[-0.12,0.05]$

$0.12[-0.12,0.36]$

$-0.12[-0.19,-0.05]$

$-0.03[-0.11,0.05]$ 


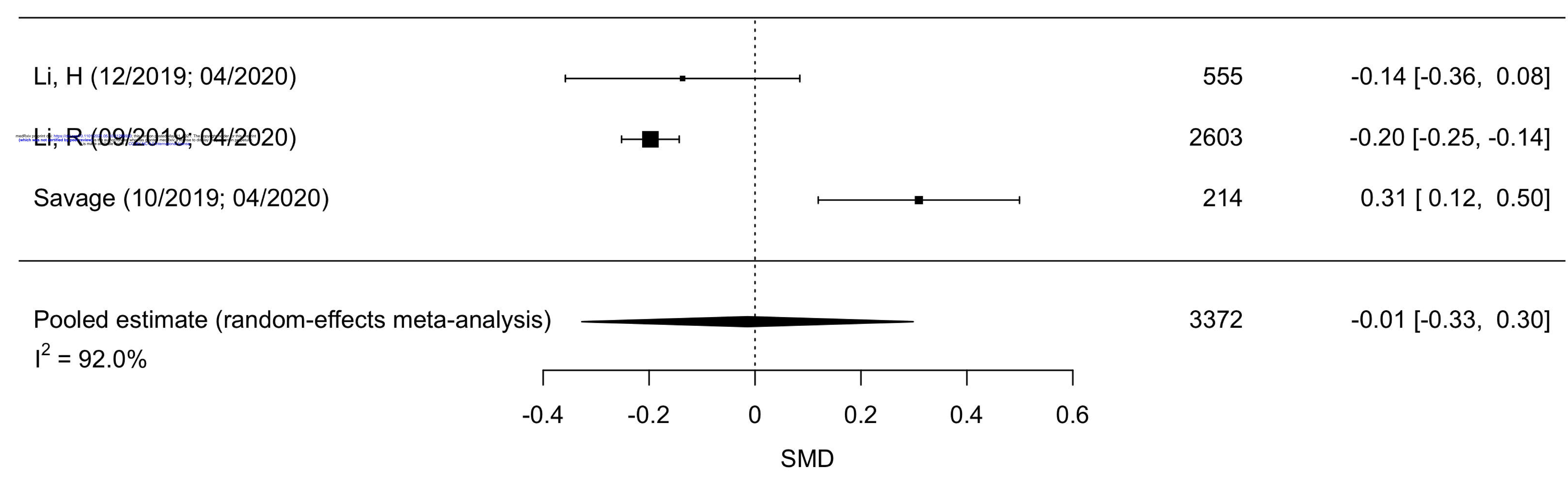




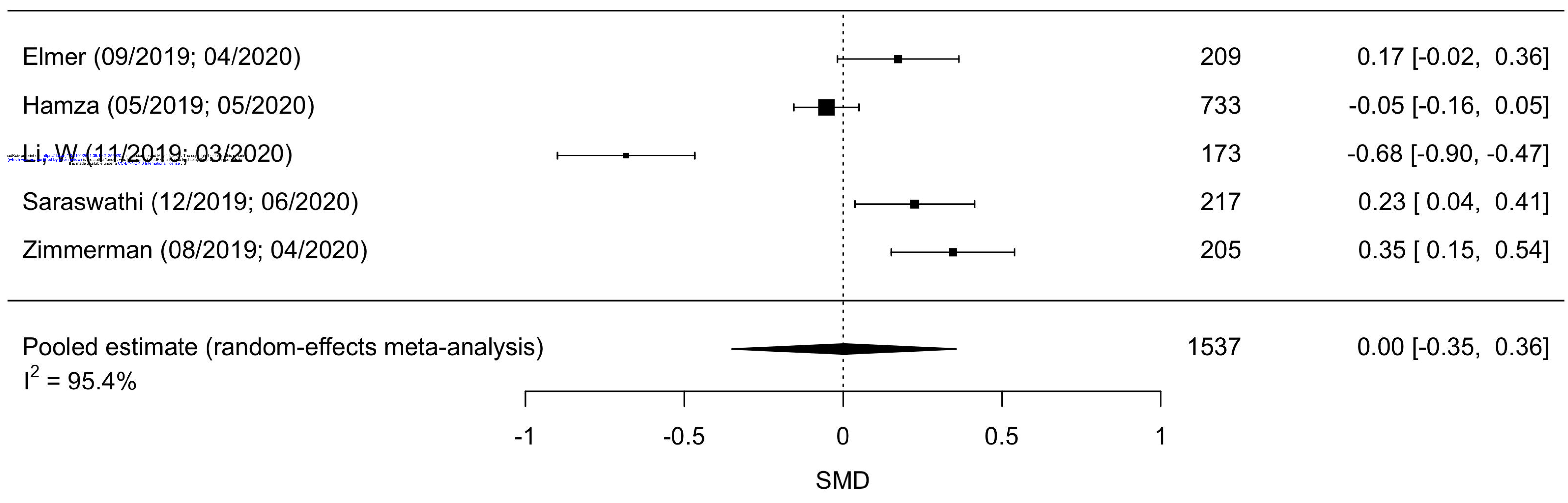




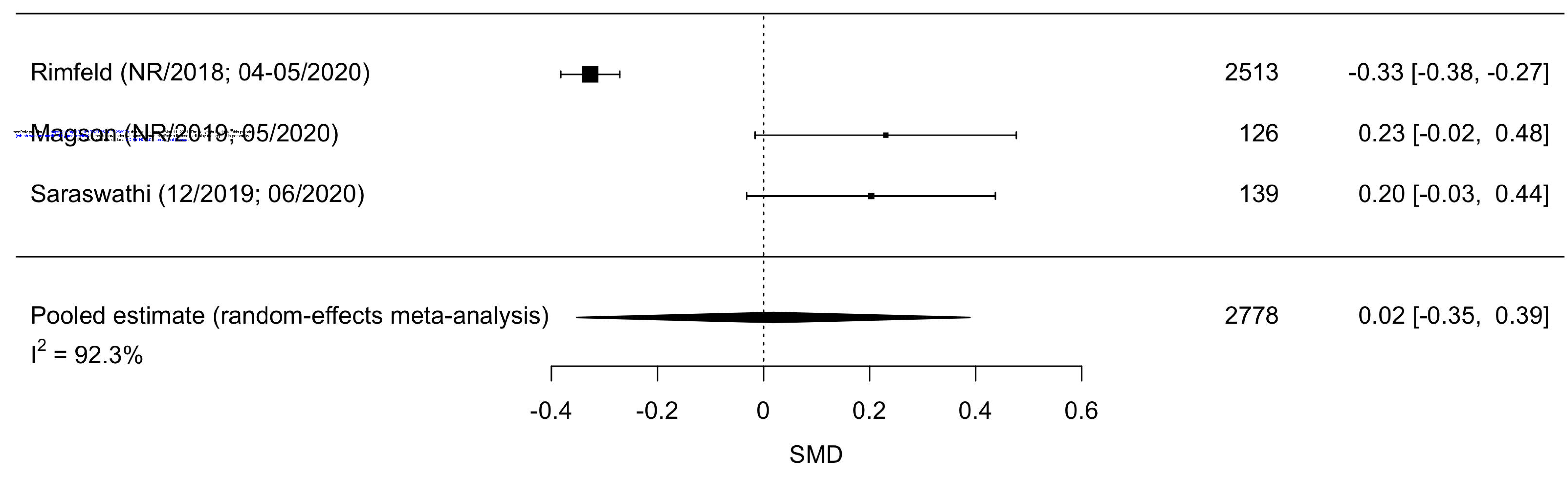




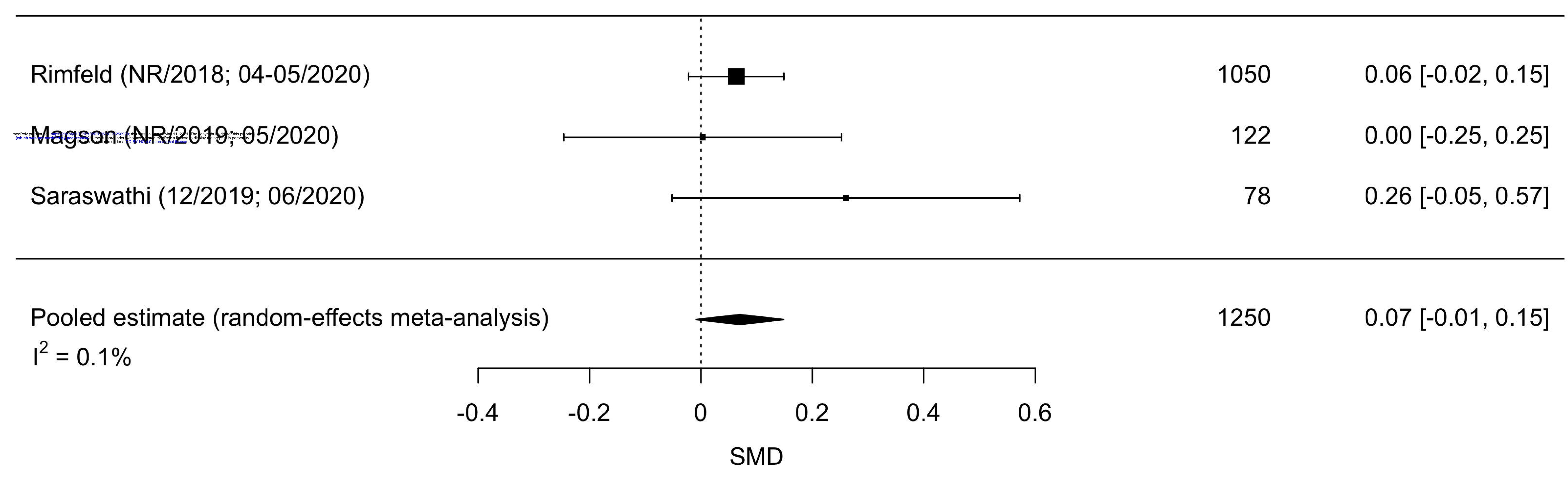




\section{Author (Pre-COVID-19; COVID-19)}

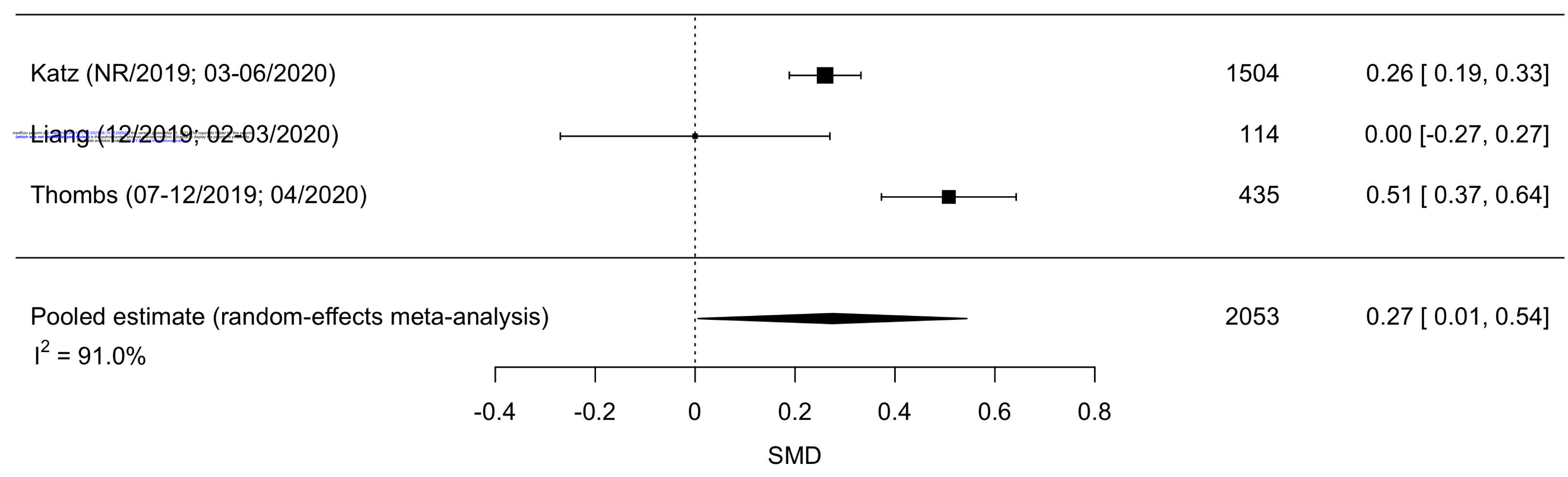




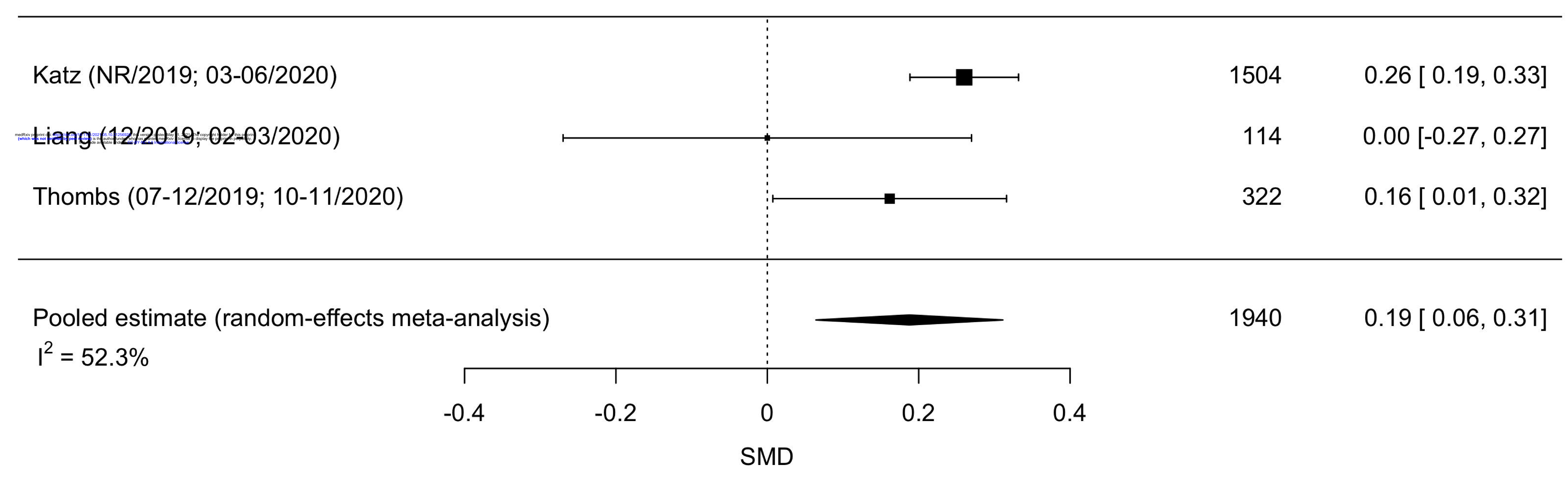




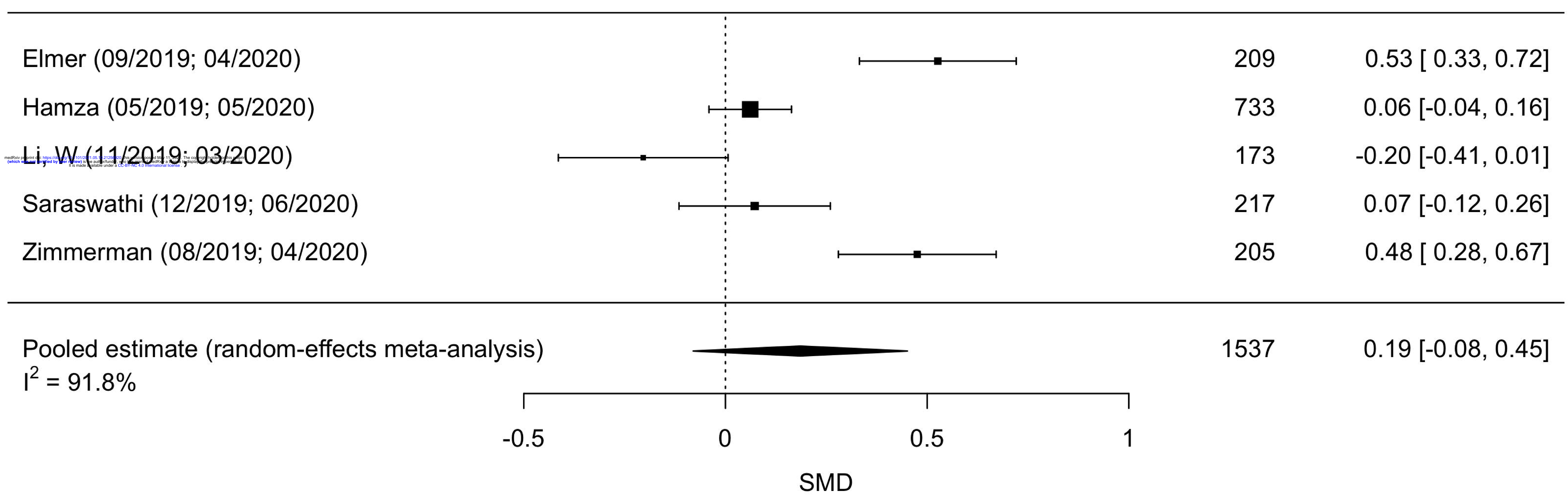




\section{Author (Pre-COVID-19; COVID-19)}

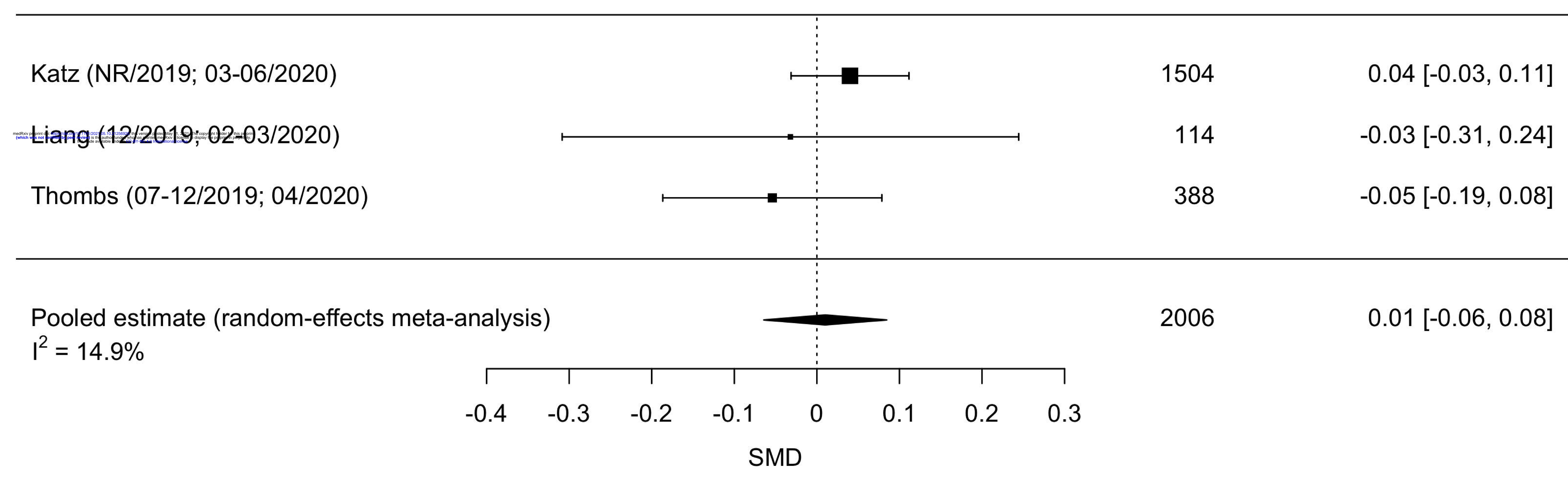




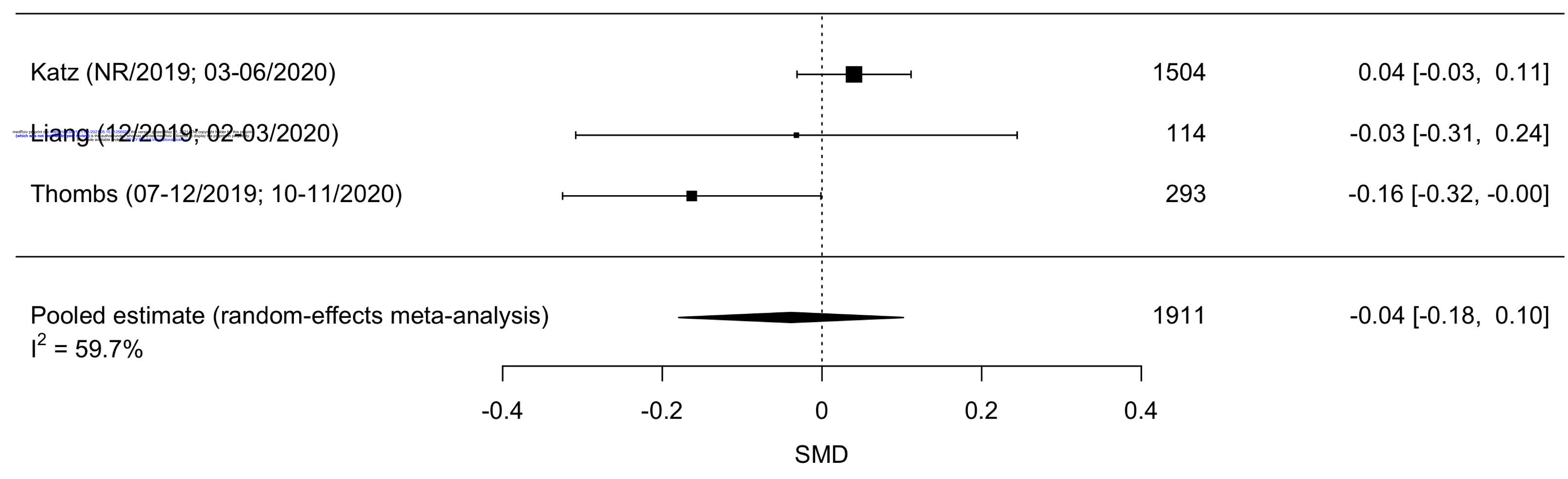




\begin{tabular}{|c|c|c|c|c|c|c|c|c|c|c|}
\hline Rimfeld (NR/2018; 04-05/2020) & & & -1 & & & & & & 2578 & $0.04[-0.02,0.09]$ \\
\hline =Magson $(\mathrm{NR} / 2019 ; 05 / 2020)$ & & & & & & & $\longrightarrow$ & & 126 & $0.58[0.33,0.83]$ \\
\hline Saraswathi $(12 / 2019 ; 06 / 2020)$ & & & & $\longrightarrow$ & & & & & 139 & $0.03[-0.21,0.26]$ \\
\hline \multicolumn{3}{|c|}{$\begin{array}{l}\text { Pooled estimate (random-effects meta-analysis) } \\
\left.\right|^{2}=91.2 \%\end{array}$} & & & & & & & \multirow[t]{3}{*}{2843} & \multirow[t]{3}{*}{$0.21[-0.14,0.55$} \\
\hline & $\Gamma$ & $T$ & T & T & T & T & T & $\neg$ & & \\
\hline & -0.4 & -0.2 & 0 & 0.2 & 0.4 & 0.6 & 0.8 & 1 & & \\
\hline
\end{tabular}


Marmet (04/2019-02/2020; 05-06/2020)

Rimfeld (NR/2018; 04-05/2020)

Magson (NR/2019; 05/2020)

Saraswathi (12/2019; 06/2020)

Pooled estimate (random-effects meta-analysis)

$I^{2}=92.3 \%$

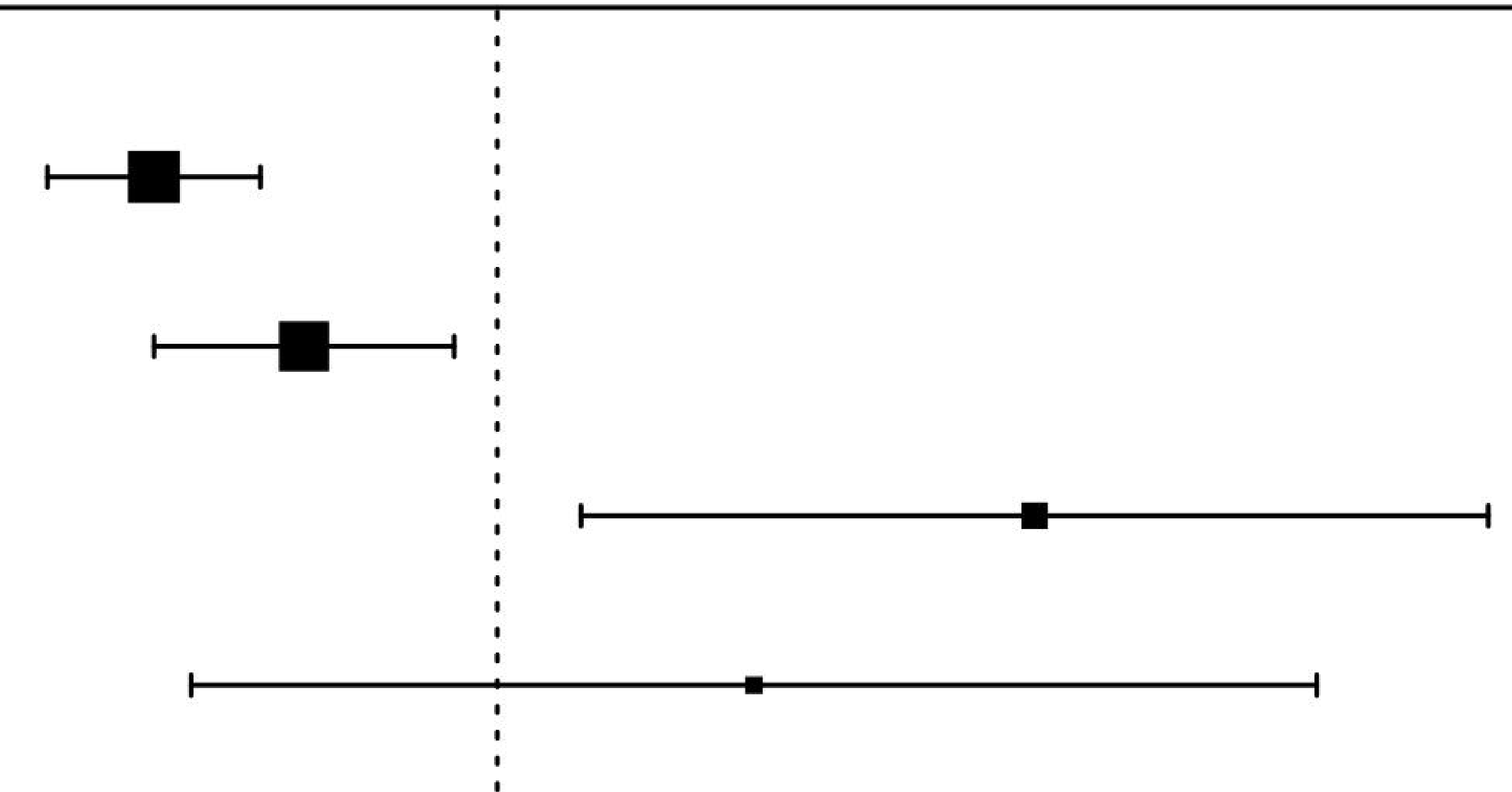

2345

1116

122

78

3661

\begin{tabular}{cc|c|ccc|c|}
\hline & & & & & \\
-0.4 & -0.2 & 0 & 0.2 & 0.4 & 0.6
\end{tabular}

$-0.19[-0.25,-0.13]$

$-0.11[-0.19,-0.02]$

$0.30[0.05,0.55]$

$0.14[-0.17,0.45]$

$0.00[-0.21,0.22]$ 